\title{
Article \\ Genomics Insights into Pseudomonas sp. CG01: An Antarctic Cadmium-Resistant Strain Capable of Biosynthesizing CdS Nanoparticles Using Methionine as S-Source
}

\author{
Carla Gallardo-Benavente ${ }^{1,2}$, Jessica L. Campo-Giraldo ${ }^{3}{ }^{(D}$, Juan Castro-Severyn ${ }^{4}$, Andrés Quiroz ${ }^{2,5, *}$ \\ and José M. Pérez-Donoso ${ }^{3, *(\mathbb{D})}$ \\ 1 Programa de Doctorado en Ciencias de Recursos Naturales, Universidad de La Frontera, \\ 4780000 Temuco, Chile; carlagallardo6@gmail.com \\ 2 Centro de Excelencia en Investigación Biotecnológica Aplicada al Medio Ambiente (CIBAMA), \\ Facultad de Ingeniería y Ciencias, Universidad de La Frontera, 4780000 Temuco, Chile \\ 3 BioNanotechnology and Microbiology Lab, Center for Bioinformatics and Integrative Biology, \\ Facultad de Ciencias de la Vida, Universidad Andres Bello, 8320000 Santiago, Chile; jek2908@gmail.com \\ 4 Laboratorio de Microbiología Aplicada y Extremófilos, Facultad de Ingeniería y Ciencias Geológicas, \\ Universidad Católica del Norte, 1240000 Antofagasta, Chile; jsevereyn@gmail.com \\ 5 Departamento de Ciencias Químicas y Recursos Naturales, Facultad de Ingeniería y Ciencias, \\ Universidad de La Frontera, 4780000 Temuco, Chile \\ * Correspondence: andres.quiroz@ufrontera.cl (A.Q.); jose.perez@unab.cl (J.M.P.-D.)
}

check for updates

Citation: Gallardo-Benavente, C.; Campo-Giraldo, J.L.; Castro-Severyn, J.; Quiroz, A.; Pérez-Donoso, J.M. Genomics Insights into Pseudomonas sp. CG01: An Antarctic Cadmium-Resistant Strain Capable of Biosynthesizing CdS Nanoparticles Using Methionine as S-Source. Genes 2021, 12, 187. https://doi.org/ 10.3390 /genes12020187

Academic Editor: Tino Polen

Received: 26 December 2020

Accepted: 22 January 2021

Published: 27 January 2021

Publisher's Note: MDPI stays neutral with regard to jurisdictional claims in published maps and institutional affiliations.

Copyright: (c) 2021 by the authors. Licensee MDPI, Basel, Switzerland. This article is an open access article distributed under the terms and conditions of the Creative Commons Attribution (CC BY) license (https:/ / creativecommons.org/licenses/by/ $4.0 /)$.

\begin{abstract}
Here, we present the draft genome sequence of Pseudomonas sp. GC01, a cadmium-resistant Antarctic bacterium capable of biosynthesizing CdS fluorescent nanoparticles (quantum dots, QDs) employing a unique mechanism involving the production of methanethiol (MeSH) from methionine (Met). To explore the molecular/metabolic components involved in QDs biosynthesis, we conducted a comparative genomic analysis, searching for the genes related to cadmium resistance and sulfur metabolic pathways. The genome of Pseudomonas sp. GC01 has a 4,706,645 bp size with a 58.61\% $\mathrm{G}+\mathrm{C}$ content. Pseudomonas sp. GC01 possesses five genes related to cadmium transport/resistance, with three P-type ATPases ( $c a d A, z n t A$, and $p b r A$ ) involved in Cd-secretion that could contribute to the extracellular biosynthesis of CdS QDs. Furthermore, it exhibits genes involved in sulfate assimilation, cysteine/methionine synthesis, and volatile sulfur compounds catabolic pathways. Regarding MeSH production from Met, Pseudomonas sp. GC01 lacks the genes E4.4.1.11 and megL for MeSH generation. Interestingly, despite the absence of these genes, Pseudomonas sp. GC01 produces high levels of $\mathrm{MeSH}$. This is probably associated with the metC gene that also produces $\mathrm{MeSH}$ from Met in bacteria. This work is the first report of the potential genes involved in Cd resistance, sulfur metabolism, and the process of MeSH-dependent CdS QDs bioproduction in Pseudomonas spp. strains.
\end{abstract}

Keywords: Antarctic bacteria; nanoparticle biosynthesis; comparative genomics; volatile sulfur compounds

\section{Introduction}

Antarctica is one of the most extreme ecosystems for the development of life on earth [1]. The harsh conditions that characterize this environment include low temperatures, high dehydration rates, high radiation, and low nutrient availability [2]. However, many microorganisms have adapted to colonize this environment by developing unique strategies to survive under these conditions. Because of this, the Antarctic continent is of great interest as a source of biodiversity and, therefore, of new biotechnological and bioactive compounds, such as enzymes, proteins, and secondary metabolites [3-5]. In this context, the use of Antarctic microorganisms as bio-factories for the production of metal-based nanocrystals or quantum dots (QDs) has been explored during the last years [6-8]. 
QDs are fluorescent semiconductor nanoparticles generally composed of CdS, CdSe, $\mathrm{ZnS}$, ZnTe, CdTe, InP, CuInS2, or GaAs, with sizes below $20 \mathrm{~nm}$ [9-12]. These nanoparticles exhibit outstanding characteristics, including broad absorption, size-dependent emission color, narrow emission profile, resistance to photobleaching, strong luminescence, and long luminescent lifetimes [12-14]. The remarkable properties of QDs are associated with the nanocrystals' size and composition [11,12]. They can be effectively tapped for several applications, such as for imaging techniques [15], solar cells [16,17], optoelectronics [18], and quantification of different molecules [19,20], among others.

The biosynthesis or biological production of QDs using microorganisms has emerged as an eco-friendly, cost effective, and highly biocompatible alternative [21,22]. Bacterial biosynthesis of cadmium-based QDs has been extensively studied during the last years because of their simplicity and the distinctive optical properties of the nanoparticles produced [7,23-25]. Most biosynthesis methods described to date have been associated with sulfur-containing molecules, such as peptides, antioxidant thiols, and hydrogen sulfide $\left(\mathrm{H}_{2} \mathrm{~S}\right)$. In general, $\mathrm{H}_{2} \mathrm{~S}$ has been reported as a source of sulfide anion $\left(\mathrm{S}^{2-}\right)$ that interacts with the cadmium ion $\left(\mathrm{Cd}^{2+}\right)$ for the formation of CdS QDs [21,24,26,27]. Nevertheless, despite the knowledge generated during the last years, the mechanism involved in CdS nanoparticle biosynthesis is still unclear.

Pseudomonas is a genus of bacteria known for its metabolic versatility and capacity to inhabit many environments, including Antarctica [28-30]. Recent research has reported that Antarctic bacteria from the Pseudomonas genus can biosynthesize CdS nanoparticles at low temperatures $\left(15^{\circ} \mathrm{C}\right)[6]$. Pseudomonas sp. GC01, previously reported as Pseudomonas fragi GC01 [6], is a psychrotolerant bacterial strain isolated from Deception Island (South Shetland archipelago, Antarctica), highly resistant to cadmium (minimal inhibitory concentration (MIC) of $1.8 \mathrm{mM} \mathrm{CdCl}_{2}$ ), and with the ability to biosynthesize CdS QDs [6,8]. Pseudomonas sp. GC01 strain can biosynthesize QDs inside cells in the presence of sulfate, sulfite, thiosulfate, cysteine (Cys), and methionine (Met) as the sole sulfur sources. On the other hand, extracellular biosynthesis of CdS QDs only occurs in the presence of Cys and Met. Interestingly, this bacterium biosynthesizes CdS QDs through a novel mechanism that uses methanethiol (MeSH) instead of $\mathrm{H}_{2} \mathrm{~S}$ as a sulfur source for nanocrystal formation [8]. In this work, we studied the genome of Pseudomonas sp. GC01 to understand the molecular and metabolic components involved in their unique mechanism to biosynthesize CdS QDs through a comparative genomic analysis.

\section{Materials and Methods}

\subsection{Bacterial Isolation and Growth Conditions}

The Pseudomonas sp. GC01 strain used in this work was isolated from a soil sample obtained from Deception Island in the South Shetland archipelago, Antarctica (S62 $58^{\prime} 06.2^{\prime \prime} \mathrm{W}$ $\left.60^{\circ} 42^{\prime} 32.5^{\prime \prime}\right)$, during the 48th Chilean Antarctic Expedition (ECA) organized by the Chilean Antarctic Institute (INACH), and previously identified as Pseudomonas fragi GC01 [6]. Bacterial cultures were grown in Luria Bertani (LB) medium [31] at $15^{\circ} \mathrm{C}$.

\subsection{DNA Extraction, Sequencing, and Assembly}

DNA was isolated with the Genomic DNA kit (UltraClean Microbial DNA Isolation Kit, Mo Bio Laboratories, Inc, Carlsbad, CA, USA) according to the manufacturer's instructions. Following this, genomic libraries were constructed using the NanoTru-Seq DNA kit (for a pair-ended with an insert size average of $420 \mathrm{pb}$ ). Next, $1.6 \mathrm{pM}$ of the libraries were loaded, and the run was performed in a MiSeq platform (Illumina). The resulting reads were filtered and trimmed by using Trimmomatic v0.30 [32], with filters of quality $(\mathrm{Q}<30)$, length $(<100)$, ambiguities $(0 \mathrm{Ns})$, and adapters that were cut. Moreover, the filtered reads were de-novo assembled using the SPAdes v3.7 software [33]. Hence, assembly quality and completeness/contamination were evaluated using Quast v5.0.2 [33] and CheckM v1.1.2 [34] software, respectively. The complete genome sequence of Pseudomonas sp. strain 
GC01 has been deposited in GenBank under the accession number JABEMH000000000.1 (BioProject: PRJNA629082).

\subsection{Genome Functional Description}

Functional assignations of the assembled genome were made through annotation with Prokka v1.13.3 [35] and EggNOG Mapper v2.0.1 [36] software. EggNOG orthologues prediction was inferred with the diamond mapping strategy and the orthologues selected was restricted to one-to-one annotation. The chromosome topology was drawn using DNAPlotter v18.0.0 [37]. Moreover, the clusters of orthologous groups (COG) classification of the Pseudomonas sp. CG01 predicted proteins were visualized through the ggplot2 R package [38].

\subsection{Pseudomonas Genomic Dataset}

A total of 28 Pseudomonas strains (including Pseudomonas sp. CG01) were used for comparative analyses. The other 27 genomes were extracted from GenBank (Supplementary Table S1), selected trying to capture considerable diversity, cold environment origin, and the presence of interesting phenotypic capacities (such as the production of volatile sulfur compounds). All 28 genomes were re-annotated with Prokka v1.13.3 [35] and EggNOG mapper v2.0.1 [36] to have a comparable set.

\subsection{Genetic Relationships and Pan-Genome Analysis}

For whole-genome comparisons, the average nucleotide identity (ANI) was calculated for the dataset, in an all-against-all pairwise manner, using pyani (Python3 module [39]), with a BLASTn approach [40] (Altschul et al., 1990). The results were visualized using pheatmap v1.0.12 R packages [41]. Moreover, the pan genome was calculated, defining the compartments by clustering the proteins families into ortholog groups based on their sequence similarity using GET_HOMOLOGUES [42] with the orthoMCL v1.4 [43] algorithm. The core genome was composed of the protein clusters present in $\geq 26$ (of the 28) genomes. The accessory genome was composed of those protein clusters present in $\leq 3$ genomes, and the clusters present in between 4 and 25 genomes were classified as the disposable genome. Moreover, starting with the alignment of the core-genome clusters, a phylogenetic reconstruction was calculated using the PARS program from the PHYLIP v3.6 package to produce a parsimony tree, which was visualized using FigTree v1.4.3.

\subsection{Phenotype Gene Search}

To identify the metal resistance/tolerance genes (especially bivalent cations) and their distribution among the genomes set, a BLASTp approach was used; also, the BacMet: Metal Resistance Experimental Database v2.0 [44] was targeted with the 28 Pseudomonas genomes, considering the e-value $\left(<1 \mathrm{E}^{-03}\right)$, query coverage $(>75 \%)$, and identity $(>70 \%)$ filters. Besides, a second database was constructed for this research based on evidence in the literature (Supplementary Table S2). On the other hand, the genes related to the interest pathways were extracted from each genome using the KEGG identifiers (from the EggNOG annotations). Then, sulfur metabolism (map00920) and cysteine/methionine metabolism (ko00270) were converted to KEGG molecular networks using KEGG Mapper [45]. Finally, the results were visualized using the ggplot2 $\mathrm{R}$ package [38].

\section{Results and Discussion}

\subsection{Genomic Features of Antarctic Pseudomonas sp. GC01}

The draft genome sequence of Pseudomonas sp. GC01 was obtained by Illumina sequencing, and the assembly was deposited in GenBank (accession number JABEMH000000000.1). The size of the Pseudomonas sp. GC01 genome was 4,706,645 bp with a guanine-cytosine (GC) content of $58.6 \%$. The genome annotation yielded 4875 predicted coding sequences (CDSs, including 2411 hypothetical proteins), 49 transference RNA (tRNA), and three ribosomal RNA (rRNA) genes on 2004 contigs (N50: 3572 bp; Figure 1a). The functional classification of 
the CDSs was performed based on clusters of orthologous groups of proteins (COGs) [46]. From the total number of CDSs (4875) found in Pseudomonas sp. GC01, 3961 (81.3\%) of them were classified in COGs functional categories, of which 721 were functionally unknown (COG S) (Figure 1b), leaving 914 that could not be classified. The largest COG categories were transcription (COG K) with 366 CDSs, corresponding to $9.2 \%$ of the total, followed by amino acid transport and metabolism (COG E), inorganic ion transport (COG P) and metabolism, and cell wall/membrane/envelope biogenesis (COG M), with 8.8\% (350 CDSs), $7.9 \%$ (316 CDSs), and 6.9\% (274 CDSs), respectively (Figure 1b).

a

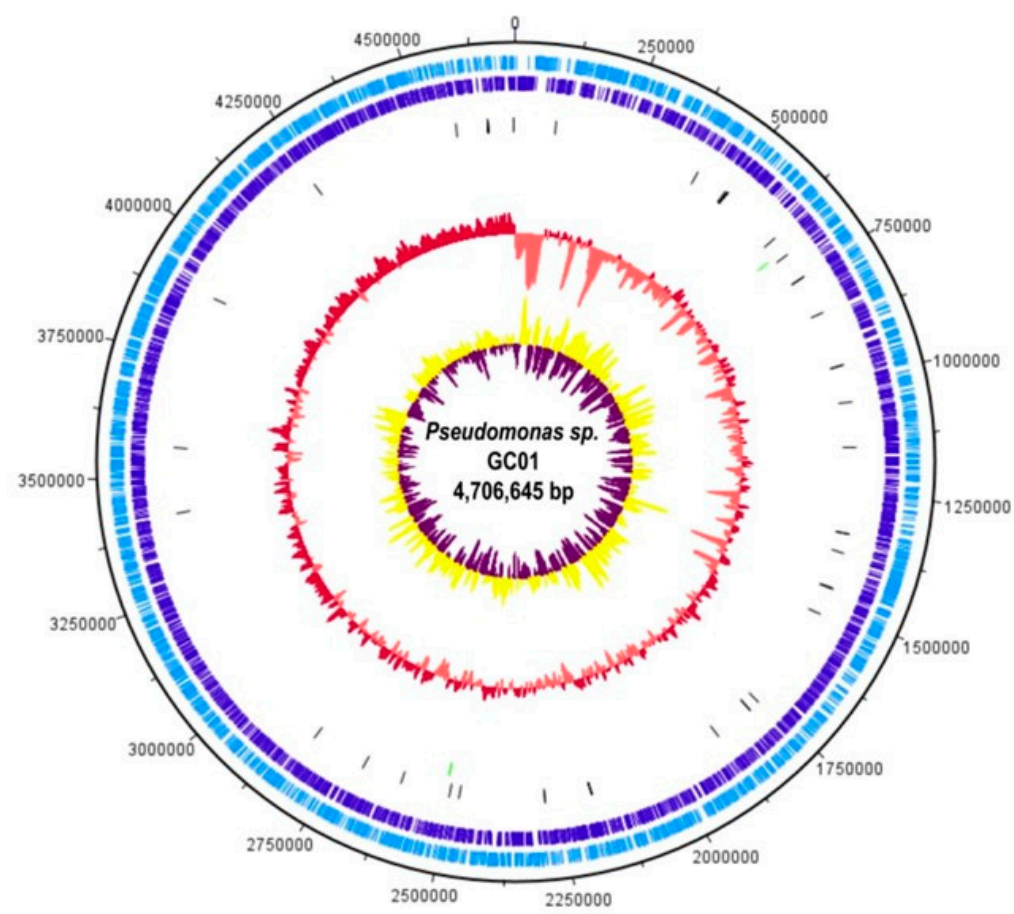

b

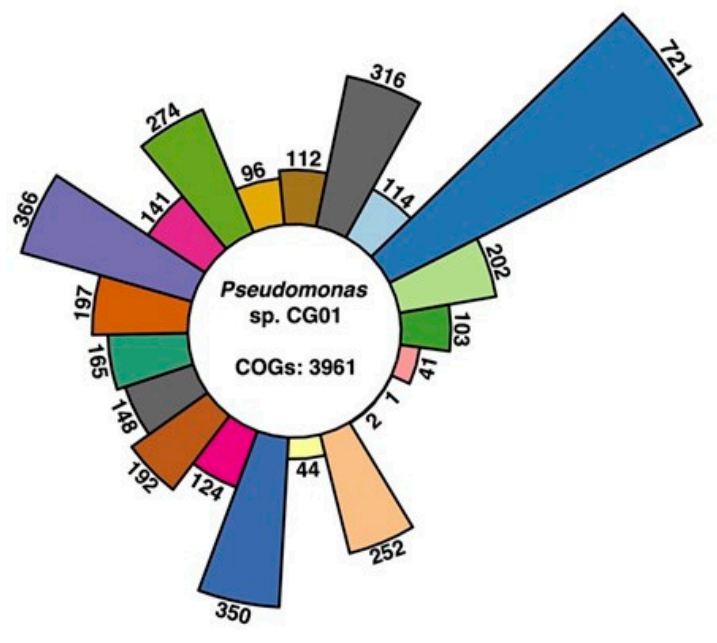

COG Categories

$\square$ A:RNA processing and modification B:Chromatin structure and dynamics C:Energy production and conversion D:Cell cycle control, division E:Amino acid transport and metabolism F:Nucleotide transport and metabolism G:Carbohydrate transport and metabolism H:Coenzyme transport and metabolism I:Lipid transport and metabolism J:Translation and ribosomal structure/biogenesis K:Transcription

L:Replication, recombination and repair M:Cell wallmembrane/envelope biogenesis $\mathrm{N}:$ Cell motility O:Post-translational modification and chaperones P:Inorganic ion transport and metabolism Q:Secondary metabolites biosynthesis, transport, and catabolism S:Function unknown T:Signal transduction mechanisms U:Intracellular trafficking and secretion v:Defense mechanisms

Figure 1. Genome characteristics of Pseudomonas sp. GC01. (a) Complete chromosome map of Pseudomonas sp. GC01. The chromosome map comprises six circles. The dark-blue and light-blue circles show the positions of the protein-coding genes on the plus and minus strands. The black bars on the third circle represent tRNA genes. The green bars on the fourth circle represent rRNA genes. The pink/red circle shows the GC content. The purple/yellow circle shows the GC skew. (b) Distribution of COG categories on the Pseudomonas sp. GC01 predicted proteins. The figure shows the number of CDSs assigned in each COG category depicted by color. 


\subsection{Genetic Relationships and Pan-Genome Analysis}

Comparative genome analysis of Pseudomonas sp. GC01 was performed using 27 Pseudomonas genome sequences available in GenBank (Supplementary Table S1). The selection criteria of the Pseudomonas strains were mainly cold environment origin and Blast sequence similarity with Pseudomonas sp. GC01. Pseudomonas strains with interesting phenotypic characteristics, such as VSC production (P. deceptionensis species; $[8,47])$, and the reference strain $P$. aeruginosa PAO1 $[48,49]$ were also included in the study.

Genome similarity of the 28 Pseudomonas strains studied was determined by average nucleotide identity (ANI) analysis [39]. The ANI values ranged from $75.3 \%$ to $99.9 \%$, indicating high diversity between the entire genomes set evaluated (Figure 2). A 99\% sequence identity was determined between Pseudomonas sp. GC01, Pseudomonas sp. Lz4W [50], and $P$. fragi P121 [51], suggesting that these strains belong to the same species. However, it is interesting that the P. fragi P121 strain did not group with the other two P. fragi strains included in the dataset, only sharing $85 \%$ identity with both strains. Moreover, the Pseudomonas sp. GC01 also closely resembles Pseudomonas sp. L.10.10 [52], with a 91\% sequence identity, followed by an $85 \%$ sequence identity to P. fragi DBC [53] and two strains of P. deceptionensis LMG25555 and DSM26521 [54,55]. Interestingly, the strains with the higher similarity to Pseudomonas sp. GC01 were isolated from cold environments, such as the Arctic (P. fragi P121 [51]) and Antarctica (Pseudomonas sp. Lz4W, Pseudomonas sp. L.10.10, and P. deceptionensis LMG25555; [50,52,54]. The P. aeruginosa strains were also the most divergent and ancestral branch among the set.

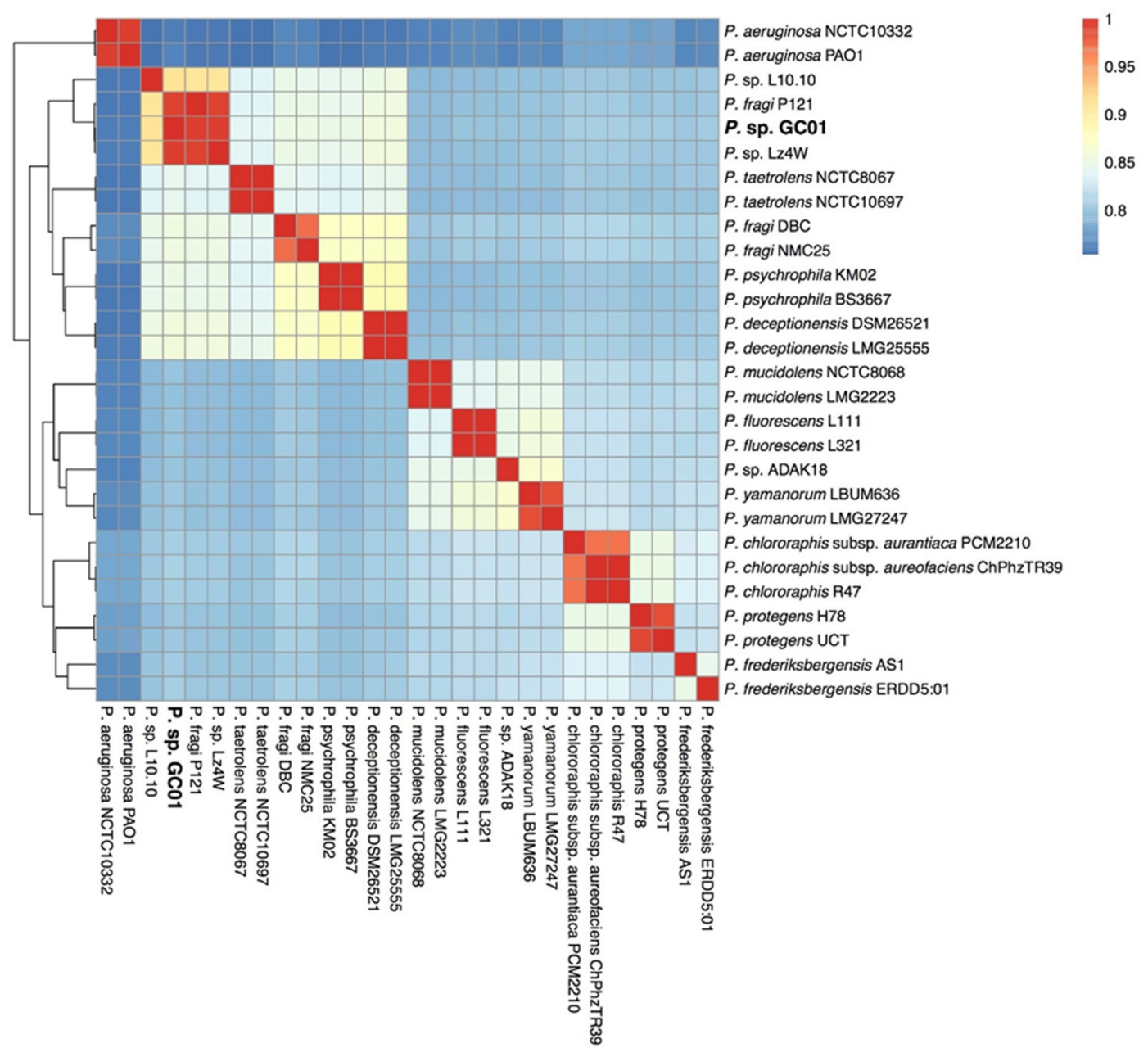

Figure 2. Heatmap displaying the relationships (hierarchical clustering) between the 28 Pseudomonas strains based on ANI analysis. The color gradients show the percentage of identity shared by each pair of genomes, from lowest (blue) to highest (red). 
The phylogenomic results further confirm the segregation of the Pseudomonas strains in several divergent modules (Figure 3a), where the P. aeruginosa strains are the most distant and ancient of the set. The Pseudomonas sp. GC01 strain shares a clade with the P. fragi P121, P. sp. Lz4W, and P. sp. L.10.10 strains, inside a branch mostly composed of strains from cold environments [50-52]. A pan-genome analysis was performed to determine if the phenotypic differences could arise from the genotypic diversity between the Pseudomonas set. The pan-genome was composed of 17,751 clusters, with only 2024 clusters $(11.4 \%)$ belonging to the core-genome compartment (Figure 3b), a result that supports the high diversity previously established between these 28 genomes. Further, considering an average of 4933 proteins coded in each genome of the 28 strains, the core compartment (2024 clusters) represent approximately $42 \%$ of the total genome (Supplementary Table S3). On the other hand, the accessory genome size ranged from 180 to 2736 clusters among the strains (Figure $3 \mathrm{~b}$ ). Remarkably, the accessory genome of Pseudomonas sp. GC01 is composed of 271 clusters, 24 of them exclusively found on this strain (22 hypothetical proteins and two possible related to stress response: the SOS response associated protein UmuD and a FAD-dependent oxidoreductase). Moreover, our data show that there is a significant fraction of the Pseudomonas sp. GC01 genome that we cannot discard as the possible origin of the particular capacities displayed by the strain. Therefore, with the improvement of bioinformatics tools and database enrichment, these mysteries will be cleared up over time [56].

a

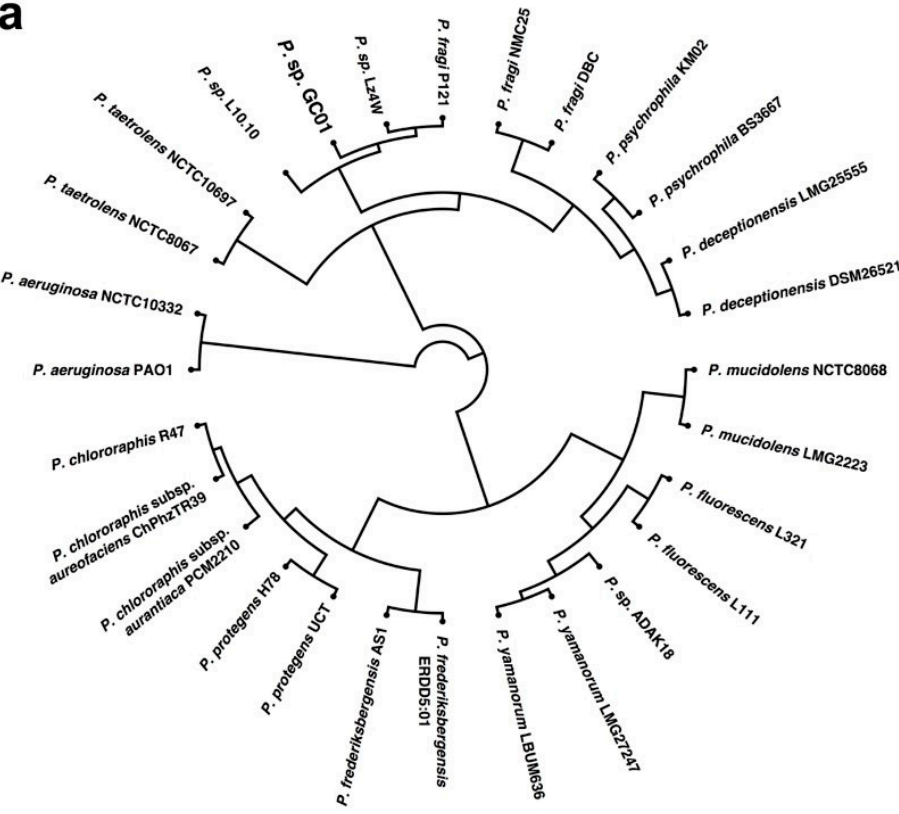

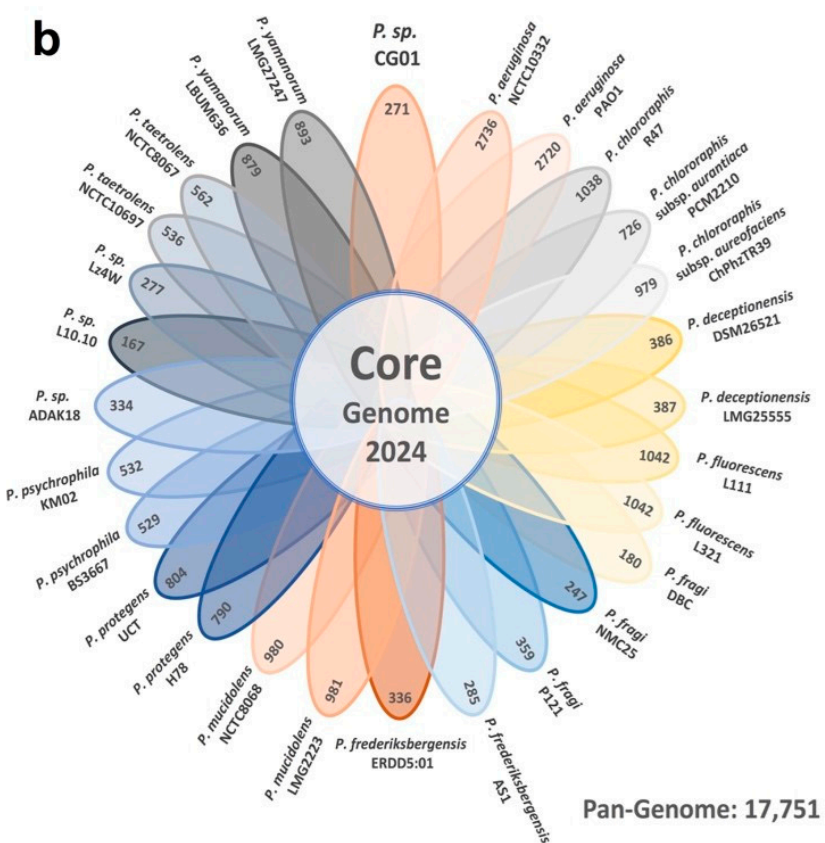

Figure 3. Phylogeny and pan-genome of 28 Pseudomonas strains. (a) Circular phylogenetic tree showing the relationships between all Pseudomonas strains, inferred based on the core-genome sequences alignment. (b) Flower diagram representing the amount of core and accessory clusters for each Pseudomonas strain considered in the pan-genome.

\subsection{Comparative Overview of Metal-Resistance Genes on Pseudomonas Strains}

Cadmium is a heavy metal with no cellular role and highly toxic for most organisms. Cadmium toxicity is associated with oxidative stress and damage to different cellular biomolecules, such as lipids, proteins, and nucleic acids [57-61]. Pseudomonas sp. GC01 is a Cd-resistant $\left(1.8 \mathrm{mM} \mathrm{CdCl}_{2}\right)$ strain that biosynthesizes CdS QDs when exposed to this metal $[6,8]$. However, the genes involved in $\mathrm{Cd}^{+2}$ tolerance/response and their implication in the biosynthesis of nanoparticles are still unknown. Based on these, we performed a bioinformatic search of metal resistance genes focusing on the Cd-resistance markers in 
all 28 Pseudomonas genomes, using the BacMet database [44] and the UniProt entries for a more specific search.

Pseudomonas genomes revealed 72 genes involved in the resistance to multidrug, oxidative stress, and metal(loid), among others (Figure 4). Forty-seven genes are involved in the uptake, tolerance, or detoxification of metal(loid)s, such as arsenic (As), antimony $(\mathrm{Sb})$, zinc $(\mathrm{Zn})$, iron $(\mathrm{Fe})$, copper $(\mathrm{Cu})$, magnesium $(\mathrm{Mg})$, manganese $(\mathrm{Mn})$, chromium $(\mathrm{Cr})$, tellurium (Te), selenium (Se), silver $(\mathrm{Ag})$, cobalt $(\mathrm{Co})$, lead $(\mathrm{Pb})$, mercury $(\mathrm{Hg})$, nickel $(\mathrm{Ni})$, and $\mathrm{Cd}$ (Figure 4). Four of these genes, $\operatorname{act} P, \operatorname{copR}, \operatorname{osc} A$, and $r u v B$, were present in all Pseudomonas strains, while other five genes, $\operatorname{ars} B, \operatorname{cad} R, \operatorname{rec} G$, $\operatorname{sod} A$, and $\operatorname{sod} B$, were absent only in one or two strains of the dataset (Figure 4). P. aeruginosa PAO1 (fpvA and PA0320), P. protegens UCT (merA, merD, merE, merP, merR, merT and pit A), and Pseudomonas sp. GC01 (mgtA) presented exclusive metal(loid) resistance genes (Figure 4), according to the BacMet database.

In general, the analysis of the 28 Pseudomonas strains indicated the presence of at least one gene related to cadmium in each genome, and a total of thirteen genes when all genomes were considered ( $c a d A, z n t A, p b r A, c a d R, c z c R, c z c S, c z c A, c z c B, c z r A, c z r B, c z r C$, $f p v A$, and PA0320; Figures 4 and 5). Most of these genes correspond to classic genomic determinants involved in cadmium response $[60,62]$ that code for bivalent cation transport pumps and regulatory systems (Figure 5) [61,63,64].

Five genes associated with $\mathrm{Cd}$ response were determined in the genome of Pseudomonas sp. GC01 (Figures 4 and 5). Three of these code for the PIB2-type ATPases (TC 3.A.3) cadA $\left(\mathrm{Cd}^{2+}\right.$ and $\left.\mathrm{Zn}^{2+}\right), z n t A\left(\mathrm{Zn}^{2+}, \mathrm{Cd}^{2+}\right.$, and $\left.\mathrm{Pb}^{2+}\right)$, and $p b r A\left(\mathrm{~Pb}^{2+}, \mathrm{Zn}^{2+}\right.$, and $\left.\mathrm{Cd}^{2+}\right)$, which are primarily involved in cadmium, zinc, and lead transport from the cytoplasm to the periplasm [61,64-67] (Figure 5). The other two genes, $c a d R$ and $c z c R$, code for the regulatory elements involved in metal resistance (Figure 5). cadR encodes a cadmiuminduced transcriptional regulatory protein involved in $\mathrm{Cd}^{2+}$ resistance in several bacteria, including Pseudomonas strains [68-70]. While, $c z c R$ has been described as a DNA-binding heavy metal response regulator, part of the $c z c R S$ two-component system, involved in $\mathrm{Cd}^{2+}$, $\mathrm{Zn}^{2+}$, and $\mathrm{Co}^{2+}$ resistance [69,71-74]. The five genes present in Pseudomonas sp. GC01 were found in most Pseudomonas strains; $c a d A$ and $c z c R$ in 22 strains, $z n t A$ and $c a d R$ in 26 strains, and $p b r A$ only in 3 strains (Figure 4 ).

Regarding the $\mathrm{Cd}^{2+}$ resistance genes $c z c A, c z c B, c z c S, c z r A, c z r B, c z r C$, fpvA, and PA0320, none of them was found in the genome of Pseudomonas sp. GC01 (Figure 4). $c z c A$ and $c z c B$ $\left(\mathrm{Cd}^{2+}, \mathrm{Zn}^{2+}\right.$, and $\left.\mathrm{Co}^{2+}\right)$, as well as $c z r A, c z r B$, and $c z r C\left(\mathrm{Cd}^{2+}\right.$, and $\left.\mathrm{Zn}^{2+}\right)$, are members of the RND family (resistance-nodulation-cell division, TC_2.A.6.3) of heavy metal efflux, that are involved in the export of $\mathrm{Cd}^{+2}$ from the periplasm to the extracellular space $[60,75-79]$. The czc family is one of the best characterized RND efflux outer membrane proteins involved in $\mathrm{Cd}^{2+}$ resistance present in many Gram-negative bacteria, including Pseudomonas [58,71-73,80]. However, $c z c A$ and $c z c B$ were absent in 12 and 26 Pseudomonas genomes, respectively, including Pseudomonas sp. GC01 (Figure 4). The genes involved in the $c z r$ efflux system were absent in $13(c z r A)$ and 26 (czrB, and $c z r C)$ Pseudomonas strains (Figure 4). Additionally, the regulatory gene $c z c S$ (part of the two-component-regulatory systems $c z c R S$ ) was present in 8 Pseudomonas strains (Figure 4). This gene encodes a heavy metal sensor histidine kinase involved in $\mathrm{Cd}^{2+}, \mathrm{Zn}^{2+}$, and $\mathrm{Co}^{2+}$ homeostasis in bacteria $[67,72]$. On the other hand, the gene $P A 0320$ has been associated with $\mathrm{Cd}^{2+}$ resistance by favoring the tolerance to reactive oxygen species (ROS; [81]). The fpvA gene $\left(\mathrm{Fe}^{3+}, \mathrm{Mn}^{2+}\right.$, $\mathrm{Co}^{2+}, \mathrm{Zn}^{2+}, \mathrm{Ni}^{2+}, \mathrm{Cu}^{2+}$, and $\mathrm{Cd}^{2+}$ ) codes for an outer membrane transporter and receptor of the siderophore pyoverdine (PVD), involved in iron uptake with a broad specificity for PVD-metal complexes in P. aeruginosa $[82,83]$. These last two genes were only found in P. aeruginosa PAO1 (Figure 4). 


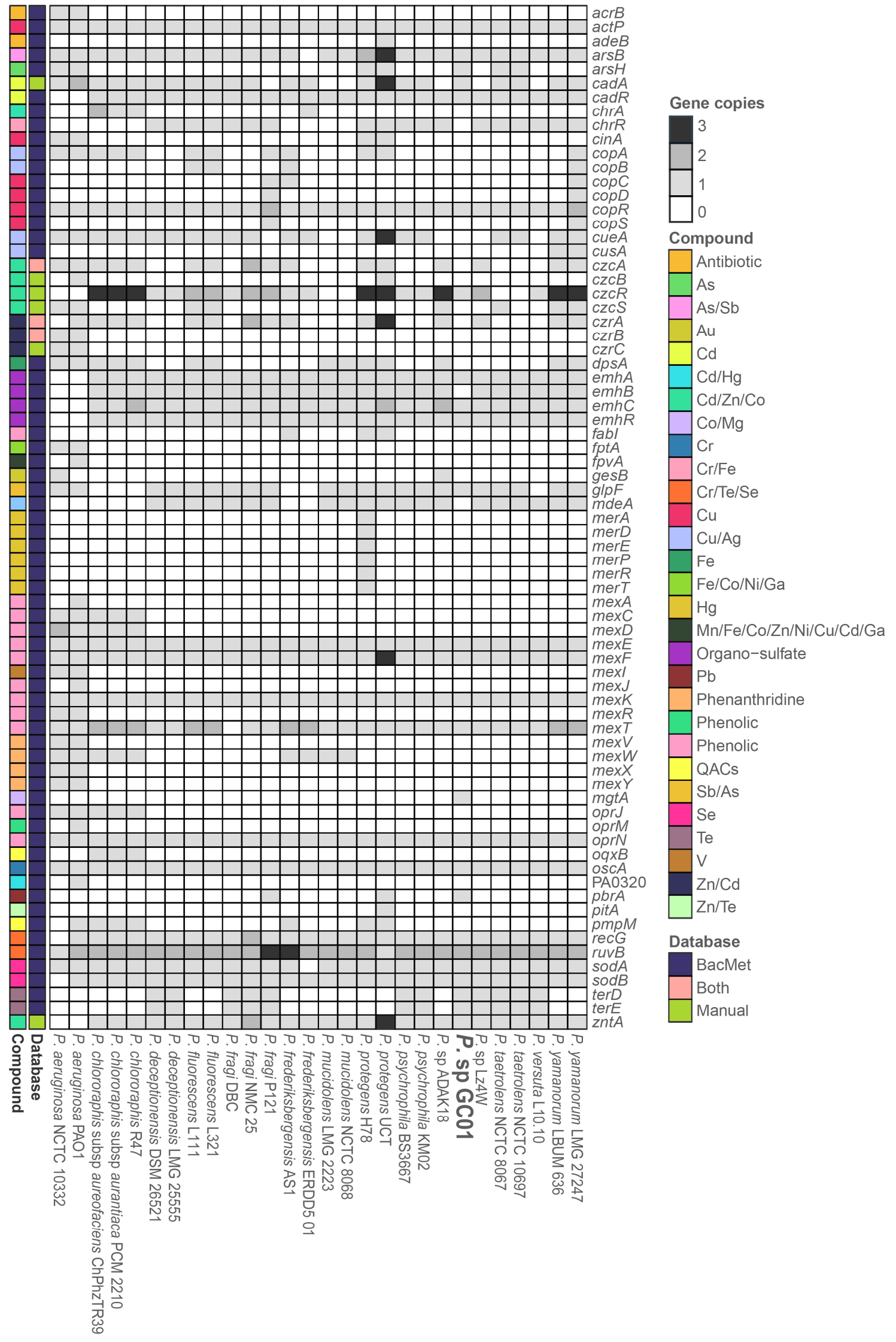

Figure 4. Heatmap of the metal-resistance genes present on the 28 Pseudomonas genomes. The scale shows the copy number of each gene in the corresponding genome, the metal(loid)/compound associated with the gene, and the database used. 


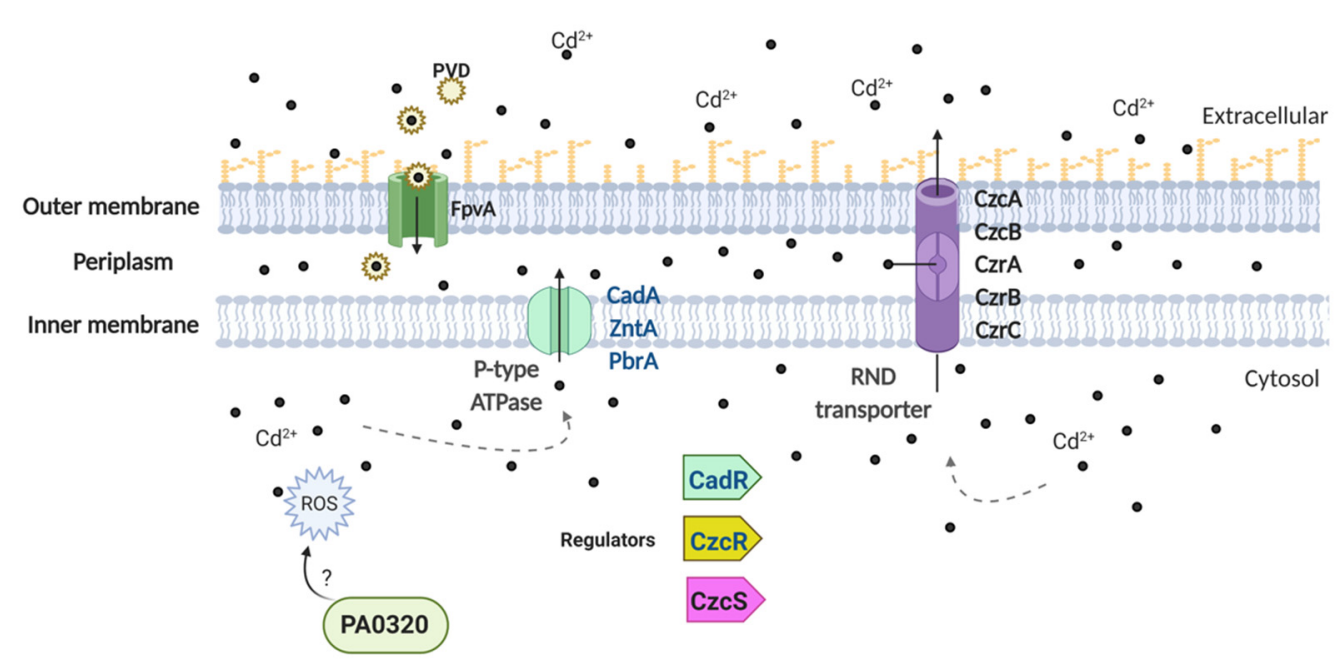

Figure 5. Schematic representation of the cadmium-resistance mechanisms based on the Pseudomonas genomes results. Protein names in blue are those found in the genome of Pseudomonas sp. GC01.

According to the results obtained, the absence of $c z c A, c z c B, c z r A, c z r B$, and $c z r C$ in Pseudomonas sp. GC01 denies the possibility of their participation in the $\mathrm{Cd}^{2+}$ transport process required for the extracellular biosynthesis of CdS. However, Pseudomonas sp. GC01 contains other genes involved in the cadmium response (Figure 4) that could participate in the biosynthesis of CdS QDs. Pseudomonas sp. GC01 cadA, zntA, and pbrA genes are candidates for $\mathrm{Cd}^{2+}$ efflux, favoring the extracellular interaction of the metal ions with sulfur-containing molecules, such as $\mathrm{H}_{2} \mathrm{~S}$ or $\mathrm{MeSH}$, to form the $\mathrm{CdS}$ nanoparticles. These genes represent three potential targets probably involved in CdS nanoparticle formation in Pseudomonas sp. GC01. However, the most novel characteristic of CdS biosynthesis in this bacterium is their capacity to synthesize nanoparticles in the presence of different sulfur sources, particularly Met.

\subsection{Comparative Analysis of Genes Involved in Sulfur Metabolism}

Since the Pseudomonas sp. GC01 can biosynthesize CdS QDs from several sulfur sources, and sulfur is a vital element in the formation of these nanoparticles, we searched for genes involved in sulfur metabolic pathways. To carry out this, we use data available in the KEGG database related to sulfur metabolism (map00920) and cysteine/methionine metabolism (ko00270). A set of 91 genes were found in the 28 Pseudomonas genomes, 39 belonging to sulfur metabolism, 52 to cysteine/methionine metabolism, and seven shared in both metabolisms (Figure 6). The genome sequences revealed the presence of numerous common genes encoding proteins related to sulfur transport, sulfate/sulfur assimilation, Cys and Met synthesis/degradation, and VSCs catabolic pathways, among others. These results are consistent with the ability of bacteria of the Pseudomonas genus to use a wide variety of organic and inorganic sulfur sources to grow [84,85].

Sulfur is an essential element required for cell growth in all bacteria [86]. It is also a necessary component in CdS nanoparticle biosynthesis $[6,24,26,87]$. The Pseudomonas sp. GC01 strain can use several sulfur sources, such as sulfate, sulfite, thiosulfate, Cys, and Met, to grow and biosynthesize CdS QDs [8]. However, the extracellular biosynthesis mechanism of the CdS nanoparticles has been linked to the ability of this strain to release $\mathrm{H}_{2} \mathrm{~S}$ and $\mathrm{MeSH}$ in the presence of Cys and Met, respectively [8]. 


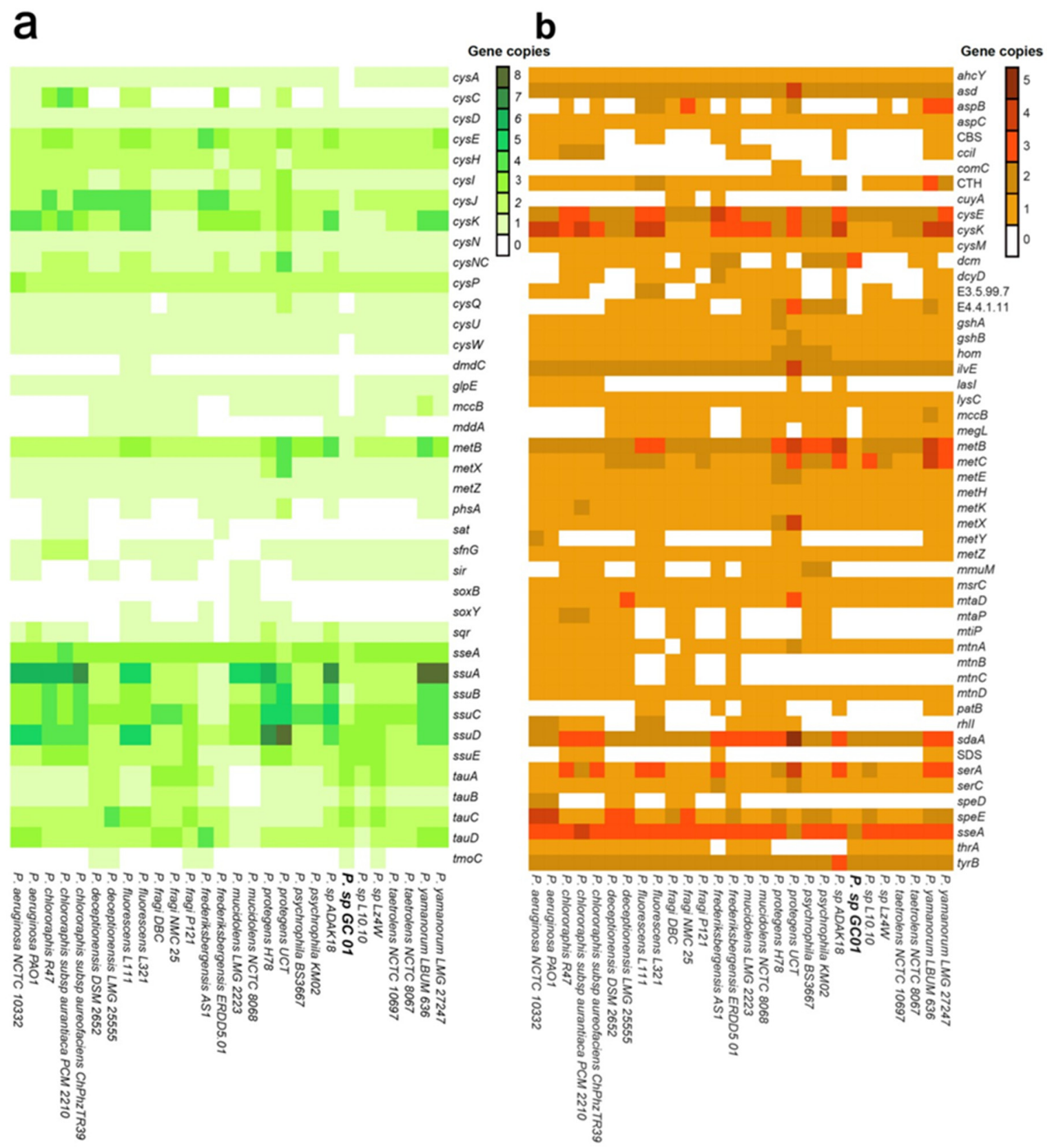

Figure 6. Heatmap of the sulfur metabolic genes present in the 28 Pseudomonas genomes analyzed. (a) Sulfur metabolism genes. (b) Cysteine and methionine metabolism genes. The heat scale shows the copy number of each gene in the corresponding genome.

Sulfate assimilation in bacteria proceeds by a sequence of similar reactions involving the uptake and activation of sulfate, followed by a stepwise reduction to sulfide $[83,88]$. The Pseudomonas genome sequences revealed that sulfate assimilation begins with the active uptake of sulfate by the ABC-type transport for sulfate/thiosulfate (encoded by cys $A$ (EC: 3.6.3.25), cysP, cys $U$, and cysW in all strains, and by cysP and cys $U$ in Pseudomonas sp. GC01) (Figure 7). Subsequently, sulfate is transformed to adenosine-5' - phosphosulphate (APS), catalyzed by ATP sulfurylase (EC: 2.7.7.4), and encoded by $c y s N$, cysD, and $c y s N C$ in the Pseudomonas strains [85], and by sat genes, which were present only in four strains (Figure 6a). Then APS can be reduced to sulfite directly through APS reductase cysH (EC: 1.8.4.10, present in all strains), or indirectly via $3^{\prime}$-phosphoadenosine- $5^{\prime}$-phosphosulfate (PAPS) that uses APS kinase cysC (EC: 2.7.1.25), followed by PAPS reductase (cysH, EC: 1.8.4.8, found in 11 Pseudomonas strains) (Figure 6a). The obtained sulfite is then reduced to 
generate sulfide by sulfite reductase encoded by cysI, cysJ (EC: 1.8.1.2), and sir (EC: 1.8.7.1), found in 19 strains, including Pseudomonas sp. GC01), before being assimilated into organic material (Figures $6 a$ and 7$)[85,89,90]$.

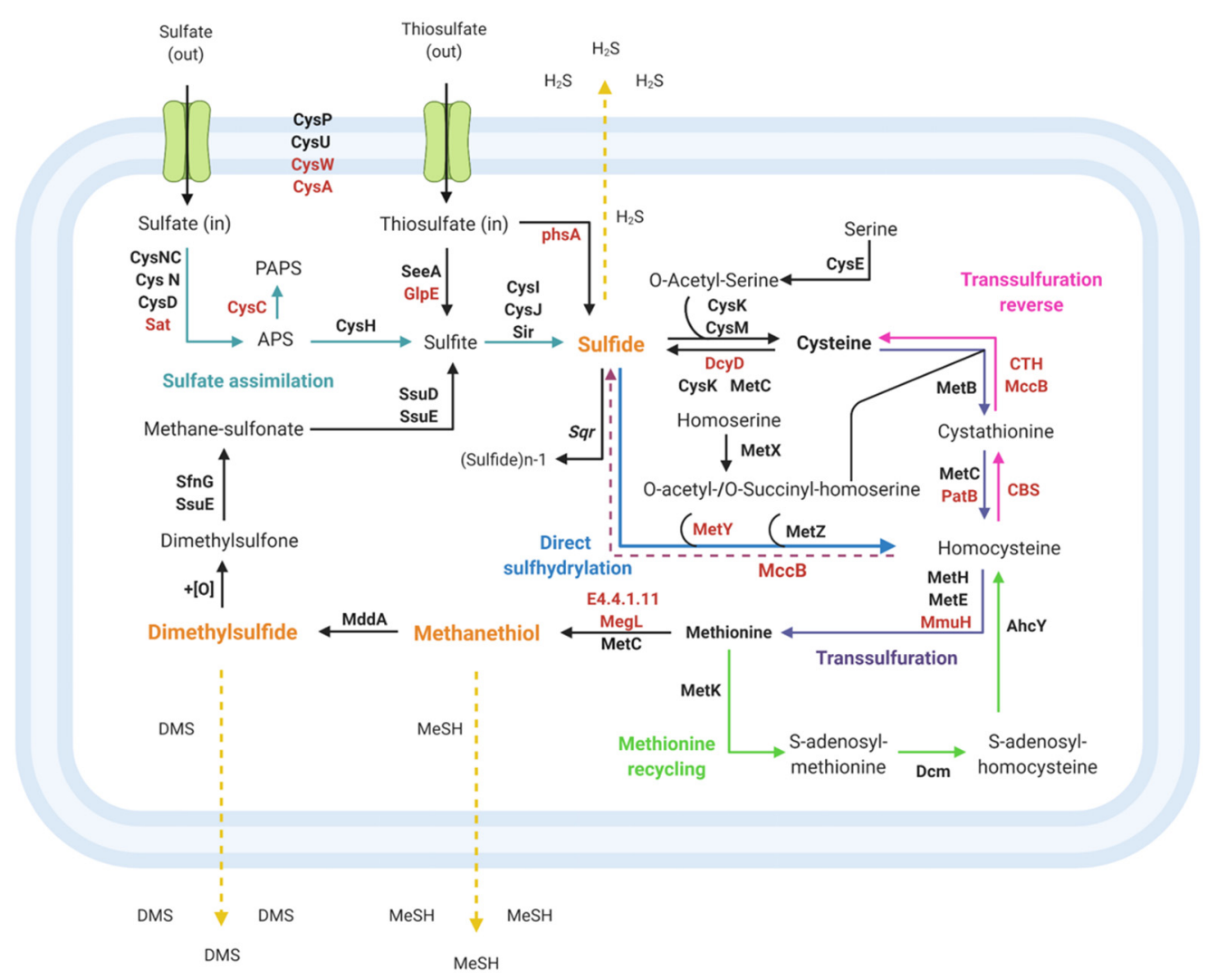

Figure 7. Sulfur metabolic pathways present in the genome of Pseudomonas sp. GC01. The schematic representation of protein identified in the genome of Pseudomonas sp. GC01 involved in sulfur assimilation, cysteine and methionine synthesis, and volatile sulfur compounds catabolic pathways. Protein names in red were not found in this strain but present in other Pseudomonas strains.

Regarding the use of sulfite and thiosulfate as inorganic sulfur sources by bacteria, sulfite can enter the sulfate assimilation pathway, where sulfite is reduced to sulfide by the enzyme sulfite reductase cysI, cysJ, and sir [89]. Thiosulfate can be incorporated through $\mathrm{ABC}$-type transporters (sulfate/thiosulfate, described above) and reduced to sulfite by thiosulfate sulfurtransferase (EC: 2.8.1.1; [91]) encoded by seeA and $g l p E$ (the latter absent only in Pseudomonas sp. GC01) before being assimilated as sulfide via the sulfate assimilation pathway (Figures 6a and 7). Additionally, 14 strains of Pseudomonas (not including Pseudomonas sp. GC01) contain in their genomes the thiosulfate reductase enzyme (phsA, EC: 1.8.5.5) that catalyzes the reduction of thiosulfate to sulfide (Figures 6a and 7) [92,93]. The sulfide generated by the different inorganic sulfur sources is incorporated into cells as cysteine by the action of the enzymes cysteine synthase cysk and cysM (EC: 2.5.1.47 and EC: 2.5.1.144 [94]) that catalyzes the addition of sulfide into Oacetyl-serine (Figure $6 \mathrm{a}, \mathrm{b}$ and Figure 7). Cys then works as the sulfur group donor, either directly or indirectly, to synthesize all other sulfur-bearing molecules in the cell, such as thiamine, glutathione, coenzyme A, and Met $[90,95]$.

Some bacteria belonging to the Pseudomonas genus can assimilate sulfur from reduced sulfur molecules, such as the amino acids Cys and Met [84]. Generally, this metabolism is associated with internal recycling processes developed by bacteria to maximize the available nutrients [96]. Cys as a sole sulfur source can be assimilated directly via the transsulfuration pathway that converts Cys to Met (Figure 7) [84,97]. This pathway was observed in all Pseudomonas genomes analyzed and produces homocysteine by the action 
of cystathionine $\gamma$-synthetase (metB, EC: 2.5.1.48) and cystathionine $\beta$-lyase (EC: 4.4.1.13) encoded by met $C$ and pat $B$ (in 9 strains; Figure 6b) [98-100]. Subsequently, homocysteine is methylated to produce Met by methionine synthases, encoded by metE or metH (EC: 2.1.1.14 or EC: 2.1.1.13 [101]) present in all strains, and by homocysteine S-methyltransferase (тmин, EC: 2.1.1.13 [102]), determined in 12 Pseudomonas strains (Figures 6b and 7).

On the other hand, Cys also may break down to release sulfide in bacteria through the enzyme cysteine desulfhydrase (EC: 4.4.1.15) [103-106]. The gene encoding this enzyme $(d c y D)$ was found in 16 strains, not including the P. aeruginosa, P. deceptionensis, Pseudomonas sp. Lz4W, Pseudomonas fragi P121, and Pseudomonas sp. GC01 strains, among others (Figure $6 \mathrm{~b}$ ). Low $\mathrm{H}_{2} \mathrm{~S}$ production in the presence of $\mathrm{Cys}$ and other sulfur sources had been reported in Pseudomonas sp. GC01 by Gallardo-Benavente et al. (2019) [8]. This report is concordant with the absence of $d c y D$ in this strain. The presence of the enzyme sulfide:quinine oxidoreductase, encoded by sqr (EC: 1.8.5.4, present in 15 strains; Figure 6a), whose function is to oxidize sulfide to polysulfide or sulfite and thiosulfate in heterotrophic bacteria such as P. aeruginosa PAO1 [107], diminishes the sulfide released by bacteria. Therefore, the $d c y D$ absence in Pseudomonas sp. GC01 suggests that sulfide production from Cys may be catalyzed by enzymes with lower cysteine desulfhydrase activity present in their genome, such as cysteine synthases (cysK) and cystathionine $\beta$-lyase (metC) (Figure 7) $[103,104]$.

The sulfide produced by the sulfate assimilation pathway or Cys degradation can be used by Pseudomonas strains to yield Met through transsulfuration (described above) and direct sulfhydrylation pathways. The direct sulfhydrylation pathway has been described as the main Met synthesis pathway in the Pseudomonas genus [85], and the critical gene (met $Z$ ) was present in all genomes analyzed (Figures $6 \mathrm{~b}$ and 7). Before Met formation, this pathway involves the direct formation of homocysteine catalyzed by the enzyme O-succinylhomoserine sulfhydrylase (metZ, EC:2.5.1.-), using O-succinyl-homoserine as substrate (Figure 6b), or the synthesis of homocysteine using O-acetyl-homoserine and sulfide (present in 8 strains) catalyzed by the O-acetyl-L-homoserine sulfhydrolase (met $Y$, EC: 2.5.1.49) [84,85,97,101,108-110].

Regarding the metabolic pathways associated with Met as a sole sulfur source for bacterial growth, the Pseudomonas genomes showed two metabolic pathways that allow conversion of this amino acid to Cys for cell growth. In the first pathway, Met may be desulfurized to produce sulfite entering in the synthetic pathway of Cys through sulfate assimilation [84]. The formation of MeSH from Met degradation catalyzed by enzyme methionine $\gamma$-lyase (EC: 4.4.1.11) has been reported in Pseudomonas [47,111,112]. The genes coding for this enzyme, megL and EC4.4.1.11, were found in 19 and 20 of the Pseudomonas genomes analyzed, respectively (Figure 6b). Despite the ability of Pseudomonas sp. GC01 to produce high concentrations of MeSH from Met, these genes were absent in their genome [8]. This result suggests that MeSH production in Pseudomonas sp. GC01 is catalyzed by an enzyme different from methionine $\gamma$-lyase. In this context, the enzyme cystathionine $\beta$-lyase (met $C$ ) has been described in some bacteria with the ability to produce MeSH from Met [113-116] and is presented as the principal candidate to carry out this function in the Pseudomonas sp. GC01 (Figure 7). Once MeSH is formed, this sulfur volatile is methylated by the enzyme methanethiol S-methyltransferase ( $m d d A$, EC: 2.1.1.334) to produce dimethylsulfide (DMS) [47], and then DMS is oxidized to dimethylsulfone [117]. Dimethylsulfone is converted to methane-sulfonate and sulfite by the action of the enzymes dimethylsulfone monooxygenase ( $s f n G$, EC: 1.14.14.35), FMN reductase (ssuE, EC 1.5.1.38), and alkanesulfonate monooxygenase (ssuD, EC: 1.14.14.5) [117]. Finally, the sulfite produced can enter the sulfate assimilation pathway for Cys biosynthesis (Figure 7) [84,117]. Two key members of Met desulfurization to sulfite are the $m d d A$ and $s f n G$ genes, which were absent in 17 and 5 Pseudomonas strains analyzed, respectively (Figure 6a). Therefore, this result showed the presence of this pathway in nine bacterial strains, including Pseudomonas sp. GC01 (Figures 6a and 7).

The second pathway that converts Met to Cys in bacteria involves methionine recycling and homocysteine conversion to Cys by reverse transsulfuration or sulfide formation 
(Figure 7) $[84,85,118]$. In general, Met is used by S-adenosylmethionine synthase (metK, EC: 2.5.1.16), present in all genomes, for the synthesis of the universal methyl donor Sadenosyl-methionine (SAM) $[85,97]$. Subsequently, SAM is regenerated or recycled to Met via the formation of homocysteine by the action of methyltransferases (encoded by $d m c$ (EC: 2.1.1.37, cytosine-specific methyltransferases) in 18 strains) and homocysteine adenosylhomocysteine ahcY (EC: 3.3.1.1) (Figures $6 \mathrm{~b}$ and 7). Then, Cys is formed by the reverse transsulfuration pathway via cystathionine by the enzymes cystathionine $\beta$-synthase (CBS, EC: 4.2.1.22) and cystathionine $\gamma$-lyase (CTH or $m c c B$, EC: 4.4.1.1) in 12 strains (Figures $6 \mathrm{~b}$ and 7 ). While, in 17 Pseudomonas strains, homocysteine desulfhydrase $m c c B$ (EC: 4.4.1.2) produces sulfide from homocysteine, which enters the Cys biosynthesis pathway via the sulfate assimilation route (Figure 7). Pseudomonas sp. GC01 lacks CBS, $C T H$, and $m c c B$ genes, suggesting that Met is used as a sulfur source in this bacterium by the Met desulfurization pathway via dimethylsulfone. However, we cannot discard that other still unknown genes or pathways could be involved in this process.

In general, no significant discrepancies were observed between the 28 Pseudomonas genomes analyzed. From a total of 84 genes observed, 33 genes were absent in some of the bacterial strains (Figure 6), probably due to the strains' genomic diversity (Figures 2 and 3). Nevertheless, sulfur is an essential element for bacterial growth. Therefore, the sulfur metabolism pathways are remarkably similar between different organisms $[85,86]$. Bacterial assimilation of sulfur into organic molecules is varied, and the sulfur metabolic pathways depend on the sulfur source used and the genomic potential of each bacteria. The genes involved in sulfate assimilation pathways, transsulfuration, direct sulfhydrylation, methionine salvage, reverse transsulfuration, VSCs catabolic pathways, among others described in this work, were found in the Pseudomonas strains analyzed (Figure 7).

Extracellular biosynthesis of CdS QDs in bacteria has been mainly associated with $\mathrm{H}_{2} \mathrm{~S}[24,87]$ and recently has been linked with $\mathrm{MeSH}$ production in Pseudomonas sp. GC01 [8]. When Cys is used as the sulfur source, the mechanism of CdS nanoparticles involves $\mathrm{H}_{2} \mathrm{~S}$ generation (as sulfide source) mediated by cysteine desulfhydrase ( $d c y D$ ) or cystathionine $\gamma$-lyase $(C T H$ or $m c c B)[26,87,119]$. Interestingly, Pseudomonas sp. GC01 biosynthesizes $\mathrm{CdS}$ nanoparticles from Cys, despite lacking these genes. Therefore, it is believed that cysK (cysteine synthases) and metC (cystathionine $\beta$-lyase) would participate in $\mathrm{H}_{2} \mathrm{~S}$ production in this strain.

Regarding the CdS QD biosynthesis associated with the production of MeSH in bacteria, Gallardo-Benavente et al. (2019) proposed a relationship between CdS nanoparticle biosynthesis and MeSH production in Pseudomonas sp. GC01, which was also linked to methionine $\gamma$-lyase activity in P. deceptionensis $\mathrm{M}^{1 \mathrm{~T}}$ [8]. However, the megL and EC4.4.1.11 genes that encode this enzyme are absent in the Pseudomonas sp. GC01 genome. This is puzzling, particularly considering the high $\mathrm{MeSH}$ production and the ability to produce CdS QDs in the presence of Met, as previously reported in this strain [8]. Accordingly, once again, metC appears as the primary candidate to carry out this function due to their ability to produce MeSH from Met in bacteria [113-116].

\section{Conclusions}

Our findings confirm the presence of three Cd efflux P-type ATPases transporters ( $c a d A, z n t A$, and $p b r A$ ) in the genome of Pseudomonas sp. GC01. Identifying these $\mathrm{Cd}^{2+}$ transport genes provides evidence about the detoxification mechanisms of cadmium in this strain, which could contribute to the extracellular biosynthesis of CdS QDs (Figure 8).

The absence of megL and EC4.4.1.11 in the Pseudomonas sp. GC01 genome discarded a role for the enzyme methionine $\gamma$-lyase in the MeSH-dependent biosynthesis of QDs CdS. However, the metC gene (coding for cystathionine $\beta$-lyase) involved in the transsulfuration pathway is the primary candidate to produce $\mathrm{MeSH}$ from Met during the extracellular biosynthesis of CdS QDs in Pseudomonas sp. GC01 (Figure 8). In addition, $\mathrm{H}_{2} \mathrm{~S}$ generation from Cys during the extracellular biosynthesis of CdS nanoparticles is most probably 
linked to cysK (cysteine synthases) and metC in Pseudomonas sp. GC01, since this strain lacks the gene $d c y D$ coding for cysteine desulfhydrase (Figure 8).

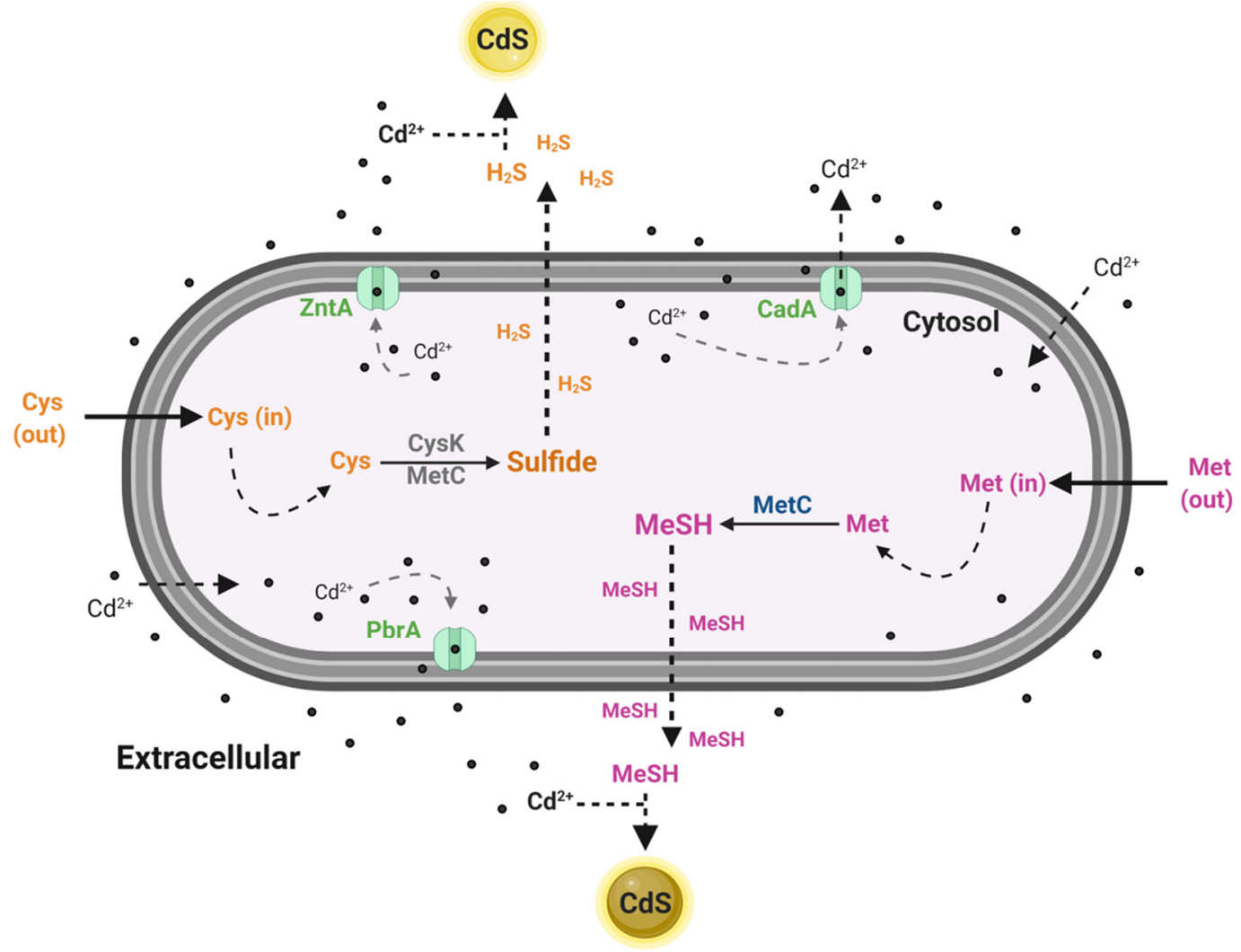

Figure 8. Schematic representation of the CdS QDs biosynthesis by Pseudomonas sp. GC01. The figure shows the proteins present in the Pseudomonas sp. GC01 genome involved in the biosynthesis of CdS nanoparticles when Cys (CysK and MetC) or Met (MetC) was used as the sulfur source as well as the $\mathrm{Cd}^{2+}$ efflux pumps CadA, ZntA, and PbrA.

Altogether, the results presented in this study constitute valuable information regarding the potential molecular mechanism involved in the bacterial biosynthesis of CdS QDs based on $\mathrm{H}_{2} \mathrm{~S}$ and $\mathrm{MeSH}$ generation, two processes scarcely known to date. Therefore, this genomic study constitutes the first report about the genes potentially involved in CdS QDs bioproduction in Pseudomonas sp. strains and the first molecular approach to a bacterial mechanism of Cd-resistance and $\mathrm{MeSH}$ production in the Antarctic strain Pseudomonas sp. GC01.

Supplementary Materials: The following are available online at https:/ /www.mdpi.com/2073-4 425/12/2/187/s1, Table S1: Accession numbers and data for the selected 28 Pseudomonas strains genomes, Table S2: Cadmium-resistance Genes Database described in the literature to Pseudomonas, Table S3: Genes Classification for each strain in the pangenome compartments.

Author Contributions: Conceptualization, C.G.-B., J.M.P.-D. and A.Q.; conceived and designed the study, J.L.C.-G. and J.C.-S.; carried out all the bioinformatics, C.G.-B., J.L.C.-G. and J.C.-S.; analyzed the data, C.G.-B.: wrote the first manuscript draft. All authors have read and agreed to the published version of the manuscript.

Funding: This research was supported by Erika Elcira Donoso Lopez, CONICYT scholarship 21151066 (C.G.-B.), Fondecyt 1200870 (J.M.P.-D.), Fondecyt 1181697 (A.Q.), INACH DT_05_16 (C.G.B., A.Q.), INACH RT-25_16 (J.M.P.-D.), CONICYT scholarship 21171644 (J.L.C.G.) and Universidad Católica del Norte 2020 Postdoctoral Fellowship (J.C.-S.).

Institutional Review Board Statement: Not applicable. 
Informed Consent Statement: Not applicable.

Data Availability Statement: The complete genome sequence of Pseudomonas sp. strain GC01 has been deposited in GenBank under the accession number JABEMH000000000.1 (BioProject: PRJNA629082).

Acknowledgments: In the loving memory of Claudio Vásquez Guzmán, an excellent friend, mentor, and scientist, but a better human being. Thanks for all the adventures and for showing us the beauty of science and friendship.

Conflicts of Interest: The authors declare that this research was conducted in the absence of any commercial or financial relationships that could be construed as a potential conflict of interest.

\section{References}

1. Cary, S.C.; McDonald, I.R.; Barrett, J.E.; Cowan, D.A. On the rocks: The microbiology of Antarctic dry valley soils. Nat. Rev. Microbiol. 2010, 8, 129-138. [CrossRef] [PubMed]

2. Wasley, J.; Robinson, S.A.; Lovelock, C.E.; Popp, M. Climate change manipulations show Antarctic flora is more strongly affected by elevated nutrients than water. Glob. Chang. Biol. 2006, 12, 1800-1812. [CrossRef]

3. Nichols, D.S.; Sanderson, K.; Buia, A.; Van de Kamp, J.; Holloway, P.; Bowman, J.P.; Smith, M.; Nichols, C.M.; Nichols, P.D.; McMeekin, T.A. Bioprospecting and biotechnology in Antarctica. In The Antarctic: Past, Present and Future, Antarctic CRC Research Report 28; Jabour-Green, J., Haward, M., Eds.; Antarctic CRC: Hobart, Australia, 2002; pp. 85-103.

4. Romoli, R.; Papaleo, M.; de Pascale, D.; Tutino, M.; Michaud, L.; LoGiudice, A.; Bartolucci, G. Characterization of the volatile profile of Antarctic bacteria by using solid-phase microextraction- gas chromatography-mass spectrometry. J. Mass Spectrom. 2011, 46, 1051-1059. [CrossRef] [PubMed]

5. Papaleo, M.; Fondi, M.; Maida, I.; Perrin, E.; Lo Giudice, A.; Michaud, L.; Mangano, S.; Bartolucci, G.; Romoli, R.; Fani, R. Sponge-associated microbial Antarctic communities exhibiting antimicrobial activity against Burkholderia cepacia complex bacteria. Biotechnol. Adv. 2012, 30, 272-293. [CrossRef] [PubMed]

6. Gallardo, C.; Monrás, J.P.; Plaza, D.O.; Collao, B.; Saona, L.A.; Durán-Toro, V.; Venegas, F.A.; Soto, C.; Ulloa, G.; Vásquez, C.C.; et al. Low-temperature biosynthesis of fluorescent semiconductor nanoparticles (CdS) by oxidative stress resistant Antarctic bacteria. J. Biotechnol. 2014, 187, 108-115. [CrossRef]

7. Plaza, D.O.; Gallardo, C.; Straub, Y.D.; Bravo, D.; Pérez-Donoso, J.M. Biological synthesis of fluorescent nanoparticles by cadmium and tellurite resistant Antarctic bacteria: Exploring novel natural nanofactories. Microb. Cell Factories 2016, 15, 76. [CrossRef]

8. Gallardo-Benavente, C.D.; Carrión, O.; Todd, J.D.; Pieretti, J.; Seabra, A.; Duran, N.; Rubilar, O.; Pérez-Donoso, J.M.; Quiroz, A.E. Biosynthesis of CdS quantum dots mediated by volatile sulfur compounds released by antarctic Pseudomonas fragi. Front. Microbiol. 2019, 10, 1866. [CrossRef]

9. Mal, J.; Nancharaiah, Y.V.; Van Hullebusch, E.D.; Lens, P.N.L. Metal chalcogenide quantum dots: Biotechnological synthesis and applications. RSC Adv. 2016, 6, 41477-41495. [CrossRef]

10. Jadhav, P.; Bhand, G.R.; Mohite, K.C.; Chaure, N.B. CdS quantum dots synthesized by low-cost wet chemical technique. In AIP Conference Proceedings; AIP Publishing: New York, NY, USA, 2017; Volume 1832, pp. 1-3. [CrossRef]

11. McHugh, K.J.; Jing, L.; Behrens, A.M.; Jayawardena, S.; Tang, W.; Gao, M.; Langer, R.; Jaklenec, A. Biocompatible Semiconductor Quantum Dots as Cancer Imaging Agents. Adv. Mater. 2018, 30, 1706356. [CrossRef]

12. Rengers, C.; Nikolai, G.; Eychmüller, A. Quantum dots and quantum rods. In Biological Responses to Nanoscale Particles; Gehr, P., Zellner, R., Eds.; NanoScienc.; Springer: Cham, Switzerland, 2019; pp. 29-51. [CrossRef]

13. Alivisatos, A.P. Perspectives on the Physical Chemistry of Semiconductor Nanocrystals. J. Phys. Chem. 1996, 100, 13226-13239. [CrossRef]

14. Zhou, M.; Ghosh, I. Quantum dots and peptides: A bright future together. Biopolymers 2007, 88, 325-339. [CrossRef] [PubMed]

15. Wagner, A.M.; Knipe, J.M.; Orive, G.; Peppas, N.A. Quantum dots in biomedical applications. Acta Biomater. 2019, 94, 44-63. [CrossRef] [PubMed]

16. Nozik, A.J.; Beard, M.C.; Luther, J.M.; Law, M.; Ellingson, R.J.; Johnson, J.C. Semiconductor quantum dots and quantum dot arrays and applications of multiple exciton generation to third-generation photovoltaic solar cells. Chem. Rev. 2010, 110, 6873-6890. [CrossRef] [PubMed]

17. Muthalif, M.P.A.; Sunesh, C.D.; Choe, Y. Enhanced light absorption and charge recombination control in quantum dot sensitized solar cells using tin doped cadmium sulfide quantum dots. J. Colloid Interface Sci. 2019, 534, 291-300. [CrossRef] [PubMed]

18. Faraon, A.; Englund, D.; Fushman, I.; Stoltz, N.; Petroff, P. Local quantum dot tuning on photonic crystal chips. Appl. Phys. Lett. 2007, 90, 213110. [CrossRef]

19. Durán-Toro, V.; Gran-scheuch, A.; Órdenes-aenishanslins, N.; Monrás, J.P.; Saona, L.A.; Venegas, F.; Chasteen, T.; Bravo, D.; Pérez-Donoso, J. Quantum dot-based assay for $\mathrm{Cu}^{2+}$ quantification in bacterial cell culture. Anal. Biochem. J. 2014, 450, 30-36. [CrossRef] [PubMed]

20. Nguyen, N.H.; Duong, T.G.; Hoang, V.N.; Pham, N.T.; Dao, T.C.; Pham, T.N. Synthesis and application of quantum dots-based biosensor. Adv. Nat. Sci. Nanosci. Nanotechnol. 2015, 6, 15015. [CrossRef] 
21. Monrás, J.P.; Díaz, V.; Bravo, D.; Montes, R.A.; Chasteen, T.G.; Osorio-Román, I.O.; Vásquez, C.C.; Pérez-Donoso, J.M. Enhanced glutathione content allows the in vivo synthesis of fluorescent CdTe nanoparticles by Escherichia coli. PLoS ONE 2012, 7, e48657. [CrossRef] [PubMed]

22. Qin, Z.; Yue, Q.; Liang, Y.; Zhang, J.; Zhou, L.; Hidalgo, O.B.; Liu, X. Extracellular biosynthesis of biocompatible cadmium sulfide quantum dots using Trametes versicolor. J. Biotechnol. 2018, 284, 52-56. [CrossRef] [PubMed]

23. Ulloa, G.; Collao, B.; Araneda, M.; Escobar, B.; Álvarez, S.; Bravo, D.; Pérez-Donoso, J.M. Use of acidophilic bacteria of the genus Acidithiobacillus to biosynthesize CdS fluorescent nanoparticles (quantum dots) with high tolerance to acidic $\mathrm{pH}$. Enzyme Microb. Technol. 2016, 95, 217-224. [CrossRef] [PubMed]

24. Yang, Z.; Lu, L.; Kiely, C.J.; Berger, B.W.; McIntosh, S. Biomineralized CdS quantum dot nanocrystals: Optimizing synthesis conditions and improving functional properties by surface modification. Ind. Eng. Chem. Res. 2016, 55, 11235-11244. [CrossRef]

25. Oliva-Arancibia, B.; Órdenes-Aenishanslins, N.; Bruna, N.; Ibarra, P.S.; Zacconi, F.C.; Pérez-Donoso, J.M.; Poblete-Castro, I. Co-synthesis of medium-chain-length polyhydroxyalkanoates and CdS quantum dots nanoparticles in Pseudomonas putida KT2440. J. Biotechnol. 2017, 264, 29-37. [CrossRef]

26. Holmes, J.D.; Richardson, D.J.; Saed, S.; Evans-Gowing, R.; Russell, D.A.; Sodeau, J.R. Cadmium-specific formation of metal sulfide 'Q-particles' by Klebsiella pneumoniae. Microbiology 1997, 143, 2521-2530. [CrossRef] [PubMed]

27. Bai, H.; Zhang, Z.; Guo, Y.; Jia, W. Biological synthesis of size-controlled cadmium sulfide nanoparticles using immobilized Rhodobacter sphaeroides. Nanoscale Res. Lett. 2009, 4, 717-723. [CrossRef]

28. Kim, J.; Park, W. Oxidative stress response in Pseudomonas putida. Appl. Microbiol. Biotechnol. 2014, 98, 6933-6946. [CrossRef]

29. Peix, A.; Ramírez-Bahena, M.-H.; Velázquez, E. The current status on the taxonomy of Pseudomonas revisited: An update. Infect. Genet. Evol. 2018, 57, 106-116. [CrossRef]

30. Ali, P.; Shah, A.A.; Hasan, F.; Cai, H.; Sosa, A.; Chen, F. Draft Genome Sequence of a Cold-Adapted Pseudomonas sp. Strain, BGI-2, Isolated from the Ice of Batura Glacier, Pakistan. Microbiol. Resour. Announc. 2019, 8, e00320-19. [CrossRef] [PubMed]

31. Sambrook, J.; Russell, D.W. Molecular Cloning, A Laboratory Manual, 3rd ed.; Cold Spring Harbor Laboratory Press: Huntington, NY, USA, 2001.

32. Bolger, A.M.; Lohse, M.; Usadel, B. Trimmomatic: A flexible trimmer for Illumina sequence data. Bioinformatics 2014, 30, 2114-2120. [CrossRef] [PubMed]

33. Gurevich, A.; Saveliev, V.; Vyahhi, N.; Tesler, G. QUAST: Quality assessment tool for genome assemblies. Bioinformatics 2013, 29, 1072-1075. [CrossRef]

34. Parks, D.H.; Imelfort, M.; Skennerton, C.T.; Hugenholtz, P.; Tyson, G.W. CheckM: Assessing the quality of microbial genomes recovered from isolates, single cells, and metagenomes. Genome Res. 2015, 25, 1043-1055. [CrossRef] [PubMed]

35. Seemann, T. Prokka: Rapid prokaryotic genome annotation. Bioinformatics 2014, 30, 2068-2069. [CrossRef] [PubMed]

36. Huerta-Cepas, J.; Forslund, K.; Coelho, L.P.; Szklarczyk, D.; Jensen, L.J.; Von Mering, C.; Bork, P. Fast genome-wide functional annotation through orthology assignment by eggNOG-mapper. Mol. Biol. Evol. 2017, 34, 2115-2122. [CrossRef] [PubMed]

37. Carver, T.; Thomson, N.; Bleasby, A.; Berriman, M.; Parkhill, J. DNAPlotter: Circular and linear interactive genome visualization. Bioinformatics 2009, 25, 119-120. [CrossRef]

38. Wickham, H. ggplot2: Elegant Graphics for Data Analysis, 2nd ed.; Springer: New York, NY, USA, 2016.

39. Pritchard, L.; Glover, R.H.; Humphris, S.; Elphinstone, J.G.; Toth, I.K. Genomics and taxonomy in diagnostics for food security: Soft-rotting enterobacterial plant pathogens. Anal. Methods 2016, 8, 12-24. [CrossRef]

40. Altschul, S.; Gish, W.; Miller, W.; Myers, E.; Lipman, D. Basic local alignment search tool. J. Mol. Biol. 1990, $215,403-410$. [CrossRef]

41. Kolde, R. Pheatmap: Pretty Heatmaps. R Package Version 1.0.8. Available online: https://CRAN.R-project.org/package= pheatmap (accessed on 20 May 2020).

42. Contreras-Moreira, B.; Vinuesa, P. GET_HOMOLOGUES, a versatile software package for scalable and robust microbial pangenome analysis. Appl. Environ. Microbiol. 2013, 79, 7696-7701. [CrossRef]

43. Li, L.; Stoeckert, C.J.; Roos, D.S. OrthoMCL: Identification of ortholog groups for eukaryotic genomes. Genome Res. 2003, 13, 2178-2189. [CrossRef]

44. Pal, C.; Bengtsson-Palme, J.; Rensing, C.; Kristiansson, E.; Larsson, D.J. BacMet: Antibacterial biocide and metal resistance genes database. Nucleic Acids Res. 2014, 42, D737-D743. [CrossRef]

45. Kanehisa, M.; Sato, Y. KEGG Mapper for inferring cellular functions from protein sequences. Protein Sci. 2019, $29,28-35$. [CrossRef]

46. Tatusov, R.L.; Galperin, M.Y.; Natale, D.A.; Koonin, E.V. The COG database: A tool for genome-scale analysis of protein functions and evolution. Nucleic Acids Res. 2000, 28, 33-36. [CrossRef]

47. Carrión, O.; Curson, A.R.J.; Kumaresan, D.; Fu, Y.; Lang, A.S.; Mercadé, E.; Todd, J.D. A novel pathway producing dimethylsulphide in bacteria is widespread in soil environments. Nat. Commun. 2015, 6, 6579. [CrossRef] [PubMed]

48. Stover, C.K.; Pham, X.Q.; Erwin, A.L.; Mizoguchi, S.D.; Warrener, P.; Hickey, M.J.; Brinkman, F.S.L.; Hufnagle, W.O.; Kowalik, D.J.; Lagrou, M.; et al. Complete genome sequence of Pseudomonas aeruginosa PAO1, an opportunistic pathogen. Nature 2000, 406, 959-964. [CrossRef] [PubMed] 
49. Klockgether, J.; Munder, A.; Neugebauer, J.; Davenport, C.F.; Stanke, F.; Larbig, K.D.; Heeb, S.; Schöck, U.; Pohl, T.M.; Wiehlmann, L.; et al. Genome diversity of Pseudomonas aeruginosa PAO1 laboratory strains. J. Bacteriol. 2010, 192, 1113-1121. [CrossRef] [PubMed]

50. Pandiyan, A.; Ray, M.K. Draft genome sequence of the Antarctic psychrophilic bacterium Pseudomonas syringae strain Lz4W. Genome Announc. 2013, 1, e00377-13. [CrossRef]

51. Yanzhen, M.; Yang, L.; Xiangting, X.; Wei, H. Complete genome sequence of a bacterium Pseudomonas fragi P121, a strain with degradation of toxic compounds. J. Biotechnol. 2016, 224, 68-69. [CrossRef]

52. See-Too, W.S.; Lim, Y.L.; Ee, R.; Convey, P.; Pearce, D.A.; Yin, W.F.; Chan, K.G. Complete genome of Pseudomonas sp. strain L10.10, a psychrotolerant biofertilizer that could promote plant growth. J. Biotechnol. 2016, 222, 84-85. [CrossRef]

53. Singha, L.P.; Kotoky, R.; Pandey, P. Draft genome sequence of Pseudomonas fragi strain DBC, which has the ability to degrade high-molecular-weight polyaromatic hydrocarbons. Genome Announc. 2017, 5, e01347-17. [CrossRef]

54. Carrión, O.; Miñana-Galbis, D.; Montes, M.J.; Mercadé, E. Pseudomonas deceptionensis sp. nov. a psychrotolerant bacterium from the Antarctic. Int. J. Syst. Evol. Microbiol. 2011, 61, 2401-2405. [CrossRef]

55. $\quad$ von Neubeck, M.; Huptas, C.; Glück, C.; Krewinkel, M.; Stoeckel, M.; Stressler, T.; Fischer, L.; Hinrichs, J.; Scherer, S.; Wenning, M. Pseudomonas helleri sp. nov. and Pseudomonas weihenstephanensis sp. nov., isolated from raw cow's milk. Int. J. Syst. Evol. Microbiol. 2016, 66, 1163-1173. [CrossRef]

56. da Costa, W.L.O.; de Aragao Araujo, C.L.; Dias, L.M.; de Sousa Pereira, L.C.; Alves, J.T.C.; Araújo, F.A.; Folador, E.L.; Henriques, I.; Silva, A.; Folador, A.R.C. Functional annotation of hypothetical proteins from the Exiguobacterium antarcticum strain B7 reveals proteins involved in adaptation to extreme environments, including high arsenic resistance. PLoS ONE 2018, 13, e0198965. [CrossRef]

57. Naz, N.; Young, H.K.; Ahmed, N.; Gadd, G.M. Cadmium accumulation and DNA homology with metal resistance genes in sulfate-reducing bacteria. Appl. Environ. Microbiol. 2005, 71, 4610-4618. [CrossRef] [PubMed]

58. Khan, Z.; Nisar, M.A.; Hussain, S.Z.; Arshad, M.N.; Rehman, A. Cadmium resistance mechanism in Escherichia coli P4 and its potential use to bioremediate environmental cadmium. Appl. Microbiol. Biotechnol. 2015, 99, 10745-10757. [CrossRef] [PubMed]

59. Abbas, S.Z.; Rafatullah, M.; Hossain, K.; Ismail, N.; Tajarudin, H.A.; Abdul Khalil, H.P.S. A review on mechanism and future perspectives of cadmium-resistant bacteria. Int. J. Environ. Sci. Technol. 2018, 15, 243-262. [CrossRef]

60. Abdelbary, S.; Elgamal, M.S.; Farrag, A. Trends in Heavy Metals Tolerance and Uptake by Pseudomonas aeruginosa. In Pseudomonas Aeruginosa-An Armory Within; Sriramulu, D., Ed.; IntechOpen: Rijeka, Croatia, 2019. [CrossRef]

61. Qin, W.; Zhao, J.; Yu, X.; Liu, X.; Chu, X.; Tian, J.; Wu, N. Improving Cadmium Resistance in Escherichia coli Through Continuous Genome Evolution. Front. Microbiol. 2019, 10, 278. [CrossRef] [PubMed]

62. Wang, A.; Crowley, D.E. Global gene expression responses to cadmium toxicity in Escherichia coli. J. Bacteriol. 2005, 187, 3259-3266. [CrossRef]

63. Stafford, S.J.; Humphreys, D.P.; Lund, P.A. Mutations in $d s b A$ and $d s b B$, but not $d s b C$, lead to an enhanced sensitivity of Escherichia coli to $\mathrm{Hg}^{2+}$ and $\mathrm{Cd}^{2+}$. FEMS Microbiol. Lett. 1999, 174, 179-184. [CrossRef]

64. Nies, D.H. The biological chemistry of the transition metal "transportome" of Cupriavidus metallidurans. Metallomics 2016, 8 , 481-507. [CrossRef]

65. Scherer, J.; Nies, D.H. CzcP is a novel efflux system contributing to transition metal resistance in Cupriavidus metallidurans CH34. Mol. Microbiol. 2009, 73, 601-621. [CrossRef]

66. Vidhyaparkavi, A.; Osborne, J.; Babu, S. Analysis of zntA gene in environmental Escherichia coli and additional implications on its role in zinc translocation. 3 Biotech 2017, 7, 9. [CrossRef]

67. Mazhar, S.H.; Herzberg, M.; Ben Fekih, I.; Zhang, C.; Bello, S.K.; Li, Y.P.; Su, J.; Xu, J.; Feng, R.; Zhou, S.; et al. Comparative Insights into the Complete Genome Sequence of Highly Metal Resistant Cupriavidus metallidurans Strain BS1 Isolated from a Gold-Copper Mine. Front. Microbiol. 2020, 11, 47. [CrossRef]

68. Permina, E.A.; Kazakov, A.E.; Kalinina, O.V.; Gelfand, M.S. Comparative genomics of regulation of heavy metal resistance in Eubacteria. BMC Microbiol. 2006, 6, 49. [CrossRef] [PubMed]

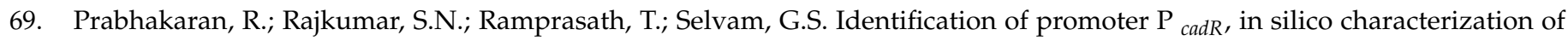
cadmium resistant gene $c a d R$ and molecular cloning of promoter $\mathrm{P}_{\text {cadR }}$ from Pseudomonas aeruginosa BC15. Toxicol. Ind. Health 2018, 34, 819-833. [CrossRef] [PubMed]

70. Cayron, J.; Effantin, G.; Prudent, E.; Rodrigue, A. Original sequence divergence among Pseudomonas putida CadRs drive specificity. Res. Microbiol. 2020, 171, 21-27. [CrossRef] [PubMed]

71. Perron, K.; Caille, O.; Rossier, C.; Delden, C.V.; Dumas, J.; Kohler, T. CzcR-CzcS, a two-component system involved in heavy metal and carbapenem resistance in Pseudomonas aeruginosa. J. Biol. Chem. 2004, 279, 8761-8768. [CrossRef]

72. Liu, P.; Chen, X.; Huang, Q.; Chen, W. The role of CzcRS two-component systems in the heavy metal resistance of Pseudomonas putida X4. Int. J. Mol. Sci. 2015, 16, 17005-17017. [CrossRef]

73. Pal, C.; Asiani, K.; Arya, S.; Rensing, C.; Stekel, D.J.; Larsson, D.J.; Hobman, J.L. Metal resistance and its association with antibiotic resistance. Adv. Microb. Physiol. 2017, 70, 261-313. [CrossRef]

74. Orellana-Saez, M.; Pacheco, N.; Costa, J.I.; Mendez, K.N.; Miossec, M.J.; Meneses, C.; Castro-Nallar, E.; Marcoleta, A.E.; PobleteCastro, I. In-depth genomic and phenotypic characterization of the Antarctic psychrotolerant strain Pseudomonas sp. MPC6 reveals unique metabolic features, plasticity, and biotechnological potential. Front. Microbiol. 2019, 10, 1154. [CrossRef] 
75. Hassan, M.; van der Lelie, D.; Springael, D.; Römling, U.; Ahmed, N.; Mergeay, M. Identification of a gene cluster, czr, involved in cadmium and zinc resistance in Pseudomonas aeruginosa. Gene 1999, 238, 417-425. [CrossRef]

76. Hu, N.; Zhao, B. Key genes involved in heavy-metal resistance in Pseudomonas putida CD2. FEMS Microbiol. Lett. 2007, 267, 17-22. [CrossRef]

77. Valencia, E.Y.; Braz, V.S.; Guzzo, C.; Marques, M.V. Two RND proteins involved in heavy metal efflux in Caulobacter crescentus belong to separate clusters within proteobacteria. BMC Microbiol. 2013, 13, 79. [CrossRef]

78. Chong, T.M.; Yin, W.F.; Chen, J.W.; Mondy, S.; Grandclément, C.; Faure, D.; Dessaux, Y.; Chan, K.G. Comprehensive genomic and phenotypic metal resistance profile of Pseudomonas putida strain S13. 1.2 isolated from a vineyard soil. AMB Express 2016, 6, 95. [CrossRef]

79. Chellaiah, E.R. Cadmium (heavy metals) bioremediation by Pseudomonas aeruginosa: A minireview. Appl. Water Sci. 2018, 8, 154. [CrossRef]

80. Choudhary, S.; Sar, P. Real-time PCR based analysis of metal resistance genes in metal resistant Pseudomonas aeruginosa strain J007. J. Basic Microbiol. 2016, 56, 688-697. [CrossRef] [PubMed]

81. Fukushima, K.; Dubey, S.K.; Suzuki, S. YgiW homologous gene from Pseudomonas aeruginosa $25 \mathrm{~W}$ is responsible for tributyltin resistance. J. Gen. Appl. Microbiol. 2012, 58, 283-289. [CrossRef]

82. Braud, A.; Hoegy, F.; Jezequel, K.; Lebeau, T.; Schalk, I.J. New insights into the metal specificity of the Pseudomonas aeruginosa pyoverdine-iron uptake pathway. Environ. Microbiol. 2009, 11, 1079-1091. [CrossRef]

83. Hannauer, M.; Braud, A.; Hoegy, F.; Ronot, P.; Boos, A.; Schalk, I.J. The PvdRT-OpmQ efflux pump controls the metal selectivity of the iron uptake pathway mediated by the siderophore pyoverdine in Pseudomonas aeruginosa. Environ. Microbiol. 2012, 14, 1696-1708. [CrossRef]

84. Vermeij, P.; Kertesz, M.A. Pathways of assimilative sulfur metabolism in Pseudomonas putida. J. Bacteriol. 1999, $181,5833-5837$. [CrossRef]

85. Kertesz, M.A. Metabolism of sulphur-containing organic compounds. In Pseudomonas; Ramos, J.L., Ed.; Springer: Boston, MA, USA, 2004; Volume 3, pp. 323-357. [CrossRef]

86. Kertesz, M.A. Bacterial transporters for sulfate and organosulfur compounds. Res. Microbiol. 2001, 152, 279-290. [CrossRef]

87. Bai, H.J.; Zhang, Z.M.; Guo, Y.; Yang, G.E. Biosynthesis of cadmium sulfide nanoparticles by photosynthetic bacteria Rhodopseudomonas palustris. Colloids Surf. B Biointerf. 2009, 70, 142-146. [CrossRef]

88. Kertesz, M.A. Riding the sulfur cycle-Metabolism of sulfonates and sulfate esters in Gram-negative bacteria. FEMS Microbiol. Rev. 2000, 24, 135-175. [CrossRef]

89. Kredich, N.M. Biosynthesis of Cysteine. EcoSal Plus 2008, 3, 1-30. [CrossRef] [PubMed]

90. Seiflein, T.A.; Lawrence, J.G. Methionine-to-Cysteine Recycling in Klebsiella aerogenes. J. Bacteriol. 2001, 183, 336-346. [CrossRef]

91. Kawano, Y.; Onishi, F.; Shiroyama, M.; Miura, M.; Tanaka, N.; Oshiro, S.; Nonaka, G.; Nakanishi, T.; Ohtsu, I. Improved fermentative L-cysteine overproduction by enhancing a newly identified thiosulfate assimilation pathway in Escherichia coli. Appl. Microbiol. Biotechnol. 2017, 101, 6879-6889. [CrossRef] [PubMed]

92. Clark, M.A.; Barrett, E.L. The phs gene and hydrogen sulfide production by Salmonella typhimurium. J. Bacteriol. 1987, 169, 2391-2397. [CrossRef] [PubMed]

93. Stoffels, L.; Krehenbrink, M.; Berks, B.C.; Unden, G. Thiosulfate reduction in Salmonella enterica is driven by the proton motive force. J. Bacteriol. 2012, 194, 475-485. [CrossRef] [PubMed]

94. Lewis, T.A.; Glassing, A.; Harper, J.; Franklin, M.J. Role for ferredoxin: NAD (P) H oxidoreductase (FprA) in sulfate assimilation and siderophore biosynthesis in Pseudomonads. J. Bacteriol. 2013, 195, 3876-3887. [CrossRef]

95. Wada, M.; Takagi, H. Metabolic pathways and biotechnological production of L-cysteine. Appl. Microbiol. Biotechnol. 2006, 73, 48-54. [CrossRef]

96. Seiflein, T.A.; Lawrence, J.G. Two transsulfurylation pathways in Klebsiella pneumoniae. J. Bacteriol. 2006, 188, 5762-5774. [CrossRef]

97. Wüthrich, D.; Wenzel, C.; Bavan, T.; Bruggmann, R.; Berthoud, H.; Irmler, S. Transcriptional regulation of cysteine and methionine metabolism in Lactobacillus paracasei FAM18149. Front. Microbiol. 2018, 9, 1261. [CrossRef]

98. Zdych, E.; Peist, R.; Reidl, J.; Boos, W. MalY of Escherichia coli is an enzyme with the activity of a beta CS lyase (cystathionase). J. Bacteriol. 1995, 177, 5035-5039. [CrossRef]

99. Auger, S.; Gomez, M.P.; Danchin, A.; Martin-Verstraete, I. The PatB protein of Bacillus subtilis is a CS-lyase. Biochimie 2005, 87, 231-238. [CrossRef]

100. Miyamoto, T.; Katane, M.; Saitoh, Y.; Sekine, M.; Homma, H. Cystathionine $\beta$-lyase is involved in d-amino acid metabolism. Biochem. J. 2018, 475, 1397-1410. [CrossRef] [PubMed]

101. Alaminos, M.; Ramos, J.L. The methionine biosynthetic pathway from homoserine in Pseudomonas putida involves the met $W$, met $X$, met $Z$, metH and metE gene products. Arch. Microbiol. 2001, 176, 151-154. [CrossRef] [PubMed]

102. Li, K.; Li, G.; Bradbury, L.M.; Hanson, A.D.; Bruner, S.D. Crystal structure of the homocysteine methyltransferase MmuM from Escherichia coli. Biochem. J. 2016, 473, 277-284. [CrossRef] [PubMed]

103. Awano, N.; Wada, M.; Kohdoh, A.; Oikawa, T.; Takagi, H.; Nakamori, S. Effect of cysteine desulfhydrase gene disruption on L-cysteine overproduction in Escherichia coli. Appl. Microbiol. Biotechnol. 2003, 62, 239-243. [CrossRef]

104. Awano, N.; Wada, M.; Mori, H.; Nakamori, S.; Takari, H. Identification and functional analysis of Escherichia coli cysteine desulfhydrases. Appl. Environ. Microbiol. 2005, 71, 4149-4152. [CrossRef] 
105. Yu, Y.; Bai, G.; Liu, C.; Li, Y.; Jin, Y.; Yang, W. Cloning, expression and characterization of L-cysteine desulfhydrase gene from Pseudomonas sp. TS1138. Front. Biol. China 2007, 2, 391-396. [CrossRef]

106. Oguri, T.; Schneider, B.; Reitzer, L. Cysteine catabolism and cysteine desulfhydrase (CdsH/STM0458) in Salmonella enterica serovar typhimurium. Biochem. J. 2012, 194, 4366-4376. [CrossRef]

107. Xia, Y.; Lü, C.; Hou, N.; Xin, Y.; Liu, J.; Liu, H.; Xun, L. Sulfide production and oxidation by heterotrophic bacteria under aerobic conditions. ISME J. 2017, 11, 2754-2766. [CrossRef]

108. Perumal, D.; Lim, C.S.; Chow, V.T.; Sakharkar, K.R.; Sakharkar, M.K. A combined computational-experimental analyses of selected metabolic enzymes in Pseudomonas species. Int. J. Biol. Sci. 2008, 4, 309-317. [CrossRef]

109. Shim, J.; Shin, Y.; Lee, I.; Kim, S.Y. L-methionine production. In Amino Acid Fermentation; Yokota, A., Ikeda, M., Eds.; Springer: Tokyo, Japan, 2016; Volume 159, pp. 153-177. [CrossRef]

110. Kulikova, V.V.; Revtovich, S.V.; Bazhulina, N.P.; Anufrieva, N.V.; Kotlov, M.I.; Koval, V.S.; Elena, A.; Morozova, E.A.; Hayashi, H.; Belyi, Y.F.; et al. Identification of O-acetylhomoserine sulfhydrylase, a putative enzyme responsible for methionine biosynthesis in Clostridioides difficile: Gene cloning and biochemical characterizations. IUBMB Life 2019, 71, 1815-1823. [CrossRef] [PubMed]

111. Fukumoto, M.; Kudou, D.; Murano, S.; Shiba, T.; Sato, D.; Tamura, T.; Harada, S.; Inagaki, K. The role of amino acid residues in the active site of L-methionine $\gamma$-lyase from Pseudomonas putida. Biosci. Biotechnol. Biochem. 2012, 76, 1275-1284. [CrossRef] [PubMed]

112. El-Sayed, A.S.; Ruff, L.E.; Ghany, S.E.A.; Ali, G.S.; Esener, S. Molecular and spectroscopic characterization of Aspergillus flavipes and Pseudomonas putida L-Methionine $\gamma$-Lyase in vitro. Appl. Biochem. Biotechnol. 2017, 181, 1513-1532. [CrossRef] [PubMed]

113. Dias, B.; Weimer, B. Conversion of methionine to thiols by lactococci, lactobacilli, and brevibacteria. Appl. Environ. Microbiol. 1998, 64, 3320-3326. [CrossRef] [PubMed]

114. Lee, W.J.; Banavara, D.S.; Hughes, J.E.; Christiansen, J.K.; Steele, J.L.; Broadbent, J.R.; Rankin, S.A. Role of cystathionine $\beta$-lyase in catabolism of amino acids to sulfur volatiles by genetic variants of Lactobacillus helveticus CNRZ 32. Appl. Environ. Microbiol. 2007, 73, 3034-3039. [CrossRef]

115. Schulz, S.; Dickschat, J.S. Bacterial volatiles: The smell of small organisms. Nat. Prod. Rep. 2007, 24, 814-842. [CrossRef]

116. Veselova, M.A.; Plyuta, V.A.; Khmel, I.A. Volatile Compounds of Bacterial Origin: Structure, Biosynthesis, and Biological Activity. Microbiology 2019, 88, 261-274. [CrossRef]

117. Endoh, T.; Kasuga, K.; Horinouchi, M.; Yoshida, T.; Habe, H.; Nojiri, H.; Omori, T. Characterization and identification of genes essential for dimethyl sulfide utilization in Pseudomonas putida strain DS1. Appl. Microbiol. Biotechnol. 2003, 62, 83-91. [CrossRef]

118. Hullo, M.F.; Auger, S.; Soutourina, O.; Barzu, O.; Yvon, M.; Danchin, A.; Martin-Verstraete, I. Conversion of methionine to cysteine in Bacillus subtilis and its regulation. J. Bacteriol. 2007, 189, 187-197. [CrossRef]

119. Dunleavy, R.; Lu, L.; Kiely, C.J.; McIntosh, S.; Berger, B.W. Single-enzyme biomineralization of cadmium sulfide nanocrystals with controlled optical properties. Proc. Natl. Acad. Sci. USA 2016, 113, 5275-5280. [CrossRef] 